\title{
Insights from Density Functional Theory on the Feasibility of Modified Reactive Dyes as Dye Sensitizers in Dye-Sensitized Solar Cell Applications
}

\author{
Shreyas S. Dindorkar ${ }^{1}$ and Anshul Yadav ${ }^{2, *(D)}$ \\ 1 Department of Chemistry, Jai Hind College, Mumbai 400020, India; shreyasdindorkar@gmail.com \\ 2 Membrane Science and Separation Technology Division, CSIR-Central Salt \& Marine Chemicals Research \\ Institute, Bhavnagar 364002, India \\ * Correspondence: anshuly@csmcri.res.in
}

check for updates

Citation: Dindorkar, S.S.; Yadav, A. Insights from Density Functional Theory on the Feasibility of Modified Reactive Dyes as Dye Sensitizers in Dye-Sensitized Solar Cell Applications. Solar 2022, 2, 12-31. https://doi.org/10.3390/ solar2010002

Academic Editor: Giuseppe Marco Tina

Received: 21 December 2021 Accepted: 15 February 2022 Published: 17 February 2022

Publisher's Note: MDPI stays neutral with regard to jurisdictional claims in published maps and institutional affiliations.

Copyright: (C) 2022 by the authors. Licensee MDPI, Basel, Switzerland. This article is an open access article distributed under the terms and conditions of the Creative Commons Attribution (CC BY) license (https:/ / creativecommons.org/licenses/by/ $4.0 /)$.

\begin{abstract}
Recently, reactive dyes have attracted a lot of attention for dye-sensitized solar cell applications. This study endeavors to design dye sensitizers with enhanced efficiency for photovoltaic cells by modifying the reactive blue 5 (RB 5) and reactive brown 10 (RB 10) dyes. Three different strategies were used to design the sensitizers, and their efficiency was compared using the density functional theory (DFT). The optimized geometry, bang gap values, the density of states, electrostatic potential surface analysis, and theoretical FT-IR absorption spectra of the sensitizers were obtained. In the first strategy, functional groups (electron-donating $\left(\mathrm{C}_{2} \mathrm{H}_{5}\right)$, electron-withdrawing $\left(-\mathrm{NO}_{2}\right)$ groups) were anchored onto dye molecules, and their effect on the charge transport properties was evaluated using the DFT analysis. The latter two designs were based on a donor- $\pi$-acceptor strategy. The second design consisted of intramolecular donor-acceptor regions separated by a benzodithiophene-based $\pi$-spacer. In the third strategy, an external acceptor unit was attached to the dye molecules through the benzodithiophene-based $\pi$-spacer. The electron-donating strengths of donor moieties in the donor- $\pi$-acceptor systems were studied using B3LYP/6-31G level DFT calculations. The quantum chemical analysis of the three designs revealed that the anchoring of functional groups $\left(-\mathrm{NO}_{2}\right.$ and $\mathrm{C}_{2} \mathrm{H}_{5}$ ) on the dye molecules showed no impact on the charge transport properties. The introduction of a benzodithiophene-based $\pi$-spacer improved the conjugation of the dye sensitizers, which enhanced the electron transport properties. The electron transport properties further improved when an external acceptor unit was attached to the dye molecule containing a $\pi$-spacer. It was thus concluded that attaching an external acceptor unit to the donor dye molecule containing a $\pi$-spacer produced desired results for both of the dyes.
\end{abstract}

Keywords: photovoltaic cells; dye sensitizer; reactive dyes; density functional theory; photosensitizer

\section{Introduction}

Over the years, unprecedented human population growth, technological advances, and industrial sectors have necessitated an increased energy supply. Renewable energy sources are expanding quickly but not enough to satisfy a strong rebound in global electricity demand. With its limitless amount, solar energy is considered one of the most promising renewable energy sources for the future [1,2]. The fact that solar energy reaching earth is four times higher than today's global energy consumption has motivated researchers to explore the domain of photovoltaics and solar cells [3-6]. Solar cells exhibit the potential of transforming solar energy into electrical energy. The second half of the 20th century witnessed advances in the first and second-generation solar cells. The emerging third-generation solar cells, such as organic/inorganic perovskite solar cells $[7,8]$, inorganic solar cells [9,10], organic tandem solar cells [11-13], quantum dot solar cells [14-16], and dye-sensitized solar cells (DSSCs) [17-19], are still in the process of commercialization [20]. Among these, the dye-sensitized solar cells (DSSCs) represent one of the most promising 
solar cell structures and are observed as a substitute for silicon solar cells [21]. The simple design and low-cost technology of DSSC further stimulated significant research interest to enhance their performance. Conventional metal sensitizer-based designs require high costs and are likely to generate toxic by-products during the synthesis procedures. Organic dyes have gained remarkable importance in DSSC applications. DSSC uses a dye instead of a semiconductor to trap light.

A Dye-sensitive photo-anode, a counter-electrode, and a redox electrolyte form a DSSC. The dye-sensitized photo-anode is responsible for light absorption and charge injection, whereas the counter-electrode reduces the redox pair. The redox electrolyte, on the other hand, is for dye reduction. An ideal photoanode for DSSCs should meet the requirements of fast electronic transport, high specific surface area, and low interfacial electron recombination [22]. The performance of the DSSC as a unit rests on the efficiency of its components as the light absorption and charge transport are separated. As a result, the advancement of each component leads to improvements in the DSSC's overall performance. The dye sensitizer is a significant and interesting part of DSSC to advance performance [23]. Among various dyes that are currently being explored for DSSC applications, reactive dyes, a family of anionic dyes, are promising candidates to design highly efficient photoanodes due to their small HLG (difference between the energies of highest occupied molecular orbitals, HOMO, and lowest unoccupied molecular orbitals, LUMO energies) leading to easier electron transportability [24-27]. Anionic dyes exhibit charge accretion regions, indicating the possibility of their ability to act as donors. Moreover, reactive dyes are rich in functional moieties; therefore, providing a scope further to enhance the efficiency of the reactive Dye-based dye sensitizers. The functional moieties enable the synthetic transformations and improve the grafting of dye molecules onto the metal oxide surface, thus making electron injection more feasible.

The challenging part in designing a DSSC is choosing suitable organic dye and its modifications [28]. Recent studies have proposed several structural changes in organic dyes to obtain a high power conversion yield. Janjua et al. [29] incorporated thiophene, 3-hexylthiophene, and 3,4-Ethyldioxythiophene as p-bridges to the structure of TH305, which resulted in indifferent electron recombination, hence, affecting the cell performances. Similarly, Tian et al. [30] showed that structural tailoring with different p-bridges caused considerable differences in the redox potential of dyes. Zhang et al. [14] showed that the extension of $\pi$ conjugation could efficiently improve the absorption intensity and red shift of the absorption spectra. Xie et al. [31,32] investigated the influence of electric field direction on the photovoltaic performance of arylamine organic dye sensitizers. DelgadoMontiel [33] studied the effect of azomethine containing $\pi$-bridges on the efficiency of the dye sensitizers. Maurya et al. [34] reported using a natural dye extracted from Cassia fistula as a photosensitizer and fabricated a $\mathrm{TiO}_{2}$-based DSSC that exhibited $\eta=0.21$. Gao et al. [35] showed that graphene quantum dots and anthoxanthin dye composites are efficient sensitizers. Ethyl red dye and its derivatives were reported to be used as material sensitizers in DSSCs [36]. The effect of geometry on the electronic properties of azo Dyebased sensitizer has been investigated [37]. Pounraj et al. [38] showed that the $\pi$-bridge configuration in the triphenylamine-based dye structures affects the electronic properties of the sensitizers. One of the most efficient and widely used strategies employed in designing the dye sensitizers is to have a donor- $\pi$ bridge-acceptor (D- $\pi-A)$ bipolar configuration. The donor group (D) is electron-rich and is linked through a conjugated linker ( $\pi$ bridge) to the electron acceptor group (A), directly anchored on the photoanode surface, such as $\mathrm{TiO}_{2}$. This dye sensitizer structure can induce the intramolecular charge transfer from the donor part to the acceptor part during photo-excitation. It is favored for effective charge separation and the injection of photoexcited electrons into the conduction band of photoanode material. However, the efficiency of the dye can be greatly improved by suitable modification on donor [39-41], $\pi$-spacer [38,42-44], and acceptor subunits [45-47]. Of these strategies, the modification at a donor moiety significantly improves the efficiency of DSSC. This is because increasing the electron-donating strength generally leads to the widening 
and intensification in the absorption region. The molecule's electronic properties greatly influence the factors that govern the efficiency of dye sensitizers, such as charge transport, photo-excitation, and electron injection. Thus, it is necessary to have a fundamental understanding of the electronic structures of the dye molecule to understand the charge separation and electron transfer separation mechanism [48,49].

Many theoreticians have successfully implemented the above-discussed approach to design dye sensitizers [50,51]. Very few reports are available on the theoretical investigation of the reactive Dye-based sensitizers to design an efficient DSSC. This work investigates novel yet simple strategies for designing reactive brown 10 (RB 10) and reactive blue 5 (RB 5)-based dye sensitizers. An attempt was made to improve the electronic transport properties of the dye molecules using three strategies. The feasibility of anchoring different functional groups at fixed positions on dye molecules was examined. The enhancement in the electronic properties of the organic counterpart was monitored with the introduction of a $\pi$-spacer between the intramolecular donor-acceptor regions. Another strategy of attaching the $\pi$-spacer to the dye molecule by an acceptor unit was tried. The density functional theory (DFT) calculations were employed to compare the efficiency of these three strategies. The electrostatic potential maps, electron localization function, the density of states (DOS) plot, and the HOMO-LUMO were obtained to understand the effect of functional groups and $\pi$-spacer on the electronic properties of the modified reactive dyes.

\section{Computational Details}

To perform the DFT level calculations, the Gaussian 09 software (Gaussian Inc., Wallingford, CT, USA) was used [52]. The molecule's geometry has great importance in determining the charge properties of the dyes [53]. To optimize the ground state geometries of the structures, the Becke, 3-parameter Lee-Yang-Parr (B3LYP) model and 6-31G basis set were used [54]. The electrostatic potential map helps gain a qualitative indication of the nature of charge transfer from the donor to the acceptor [55]. The quantification of the electron-donating strength of donors in the donor- $\pi$-acceptor system was examined by the electrostatic potential analysis using the Avogadro package [56]. The electrostatic potential at point $r$ in the vicinity of a molecular system in the atomic unit can be calculated from the electron density using the following equation [57].

$$
V(r)=\sum_{A}^{N} \frac{Z_{A}}{\left|r-R_{A}\right|}-\int \frac{\rho\left(r^{\prime}\right) d r^{\prime}}{\left|r-r^{\prime}\right|}
$$

where $N$ is the total number of nuclei present in the molecular system, $Z_{A}$ is the charge on the nucleus $A$ at a distance $R_{A}, r^{\prime}$ is a dummy integration variable, and $\rho\left(r^{\prime}\right)$ is the electron density.

To obtain the electron localization functions, which measure the likelihood of an electron in the neighburhood space of a reference atom, the Multiwfn package [58] was used.

$$
E L F(r)=\frac{1}{1+\chi_{\sigma}^{2}(r)}
$$

where $\chi_{\sigma}$ is a dimensionless localization index that expresses electron localization for the uniform electron gas.

The frontier molecular orbital spacing and their energies play a crucial role in influencing the DSSC system's charge transport [28]. The Avogadro package was used to perform frontier molecular orbital analysis and determine the HOMO-LUMO distribution of the optimized geometries. The HLG was calculated using the following equation:

$$
\mathrm{HLG}=\mathrm{E}_{\mathrm{LUMO}}-\mathrm{E}_{\mathrm{HOMO}}
$$


The density of states (DOS) of the modified dye sensitizer was calculated using the Gaussum package [59]. The DOS indicates the number of different states at a particular energy level that electrons are allowed to occupy [60].

\section{Design of RB 5 and RB 10-Based Dye Sensitizers}

Dye sensitizers based on the RB 5 and RB 10 dyes (Figure 1) were designed and tested using quantum chemical calculations for improved electron transportability.<smiles></smiles><smiles></smiles>

Figure 1. Chemical structures of (a) RB 5 and (b) RB 10 dye.

Three different strategies were employed for the modification of the dyes.

(i) A suitable functional group $(-\mathrm{Cl})$ was replaced in the dye molecules with an electrondonating $-\mathrm{C}_{2} \mathrm{H}_{5}(\mathrm{Et})$ group and an electron-withdrawing $-\mathrm{NO}_{2}$ group.

The yield and the synthetic feasibility are the two critical factors that govern the DSSC production's economic viability. Reactive dyes have a variety of functional groups attached to the core phenyl rings, and thus, a variety of transformations are possible. Due to a variety of functional moieties in reactive dyes, transformations on them are feasible. However, transformations involving the replacement of $-\mathrm{Cl}$ groups with desired moieties are much simpler [61]. Hence, the $-\mathrm{Cl}$ group on both the dye molecules was replaced with desired groups, namely $-\mathrm{C}_{2} \mathrm{H}_{5}(\mathrm{Et})$ and $-\mathrm{NO}_{2}$.

Both RB 5 and RB 10 dyes showed intramolecular donor (aromatic ring) and acceptor (triazine ring) regions [62]. One of the major reasons for selecting reactive dyes with intramolecular donor and acceptor regions is their synthetic feasibility. Identification of the intramolecular donor and acceptor groups in a dye molecule can help design an effective sensitizer during the synthetic process of a dye molecule. This can significantly reduce the use of materials, eliminate the toxic by-products, and improve the economic viability of the process. The choice of a $\pi$-spacer greatly influences the activity of the sensitizer molecule and hence the efficiency of the DSSC [25]. Nithyanandan et al. [63] reported that a benzodithiophene $\pi$-spacer (Figure 3 ) with alkyl chains improved efficiency. The reported benzodithiophene-based $\pi$-spacer was chosen (coded as BDTA) to design a dye sensitizer based on the donor- $\pi$-acceptor strategy.

(ii) (Intramolecular donor and acceptor units of the dyes were identified and connected with the BDTA spacer, as depicted in Figure 3.

(iii) The $\pi$-spacer was attached externally to the dye molecule at a suitable position, followed by the attachment of an acceptor group, cyanoacrylic acid (coded as A), as depicted in Figure 2. 


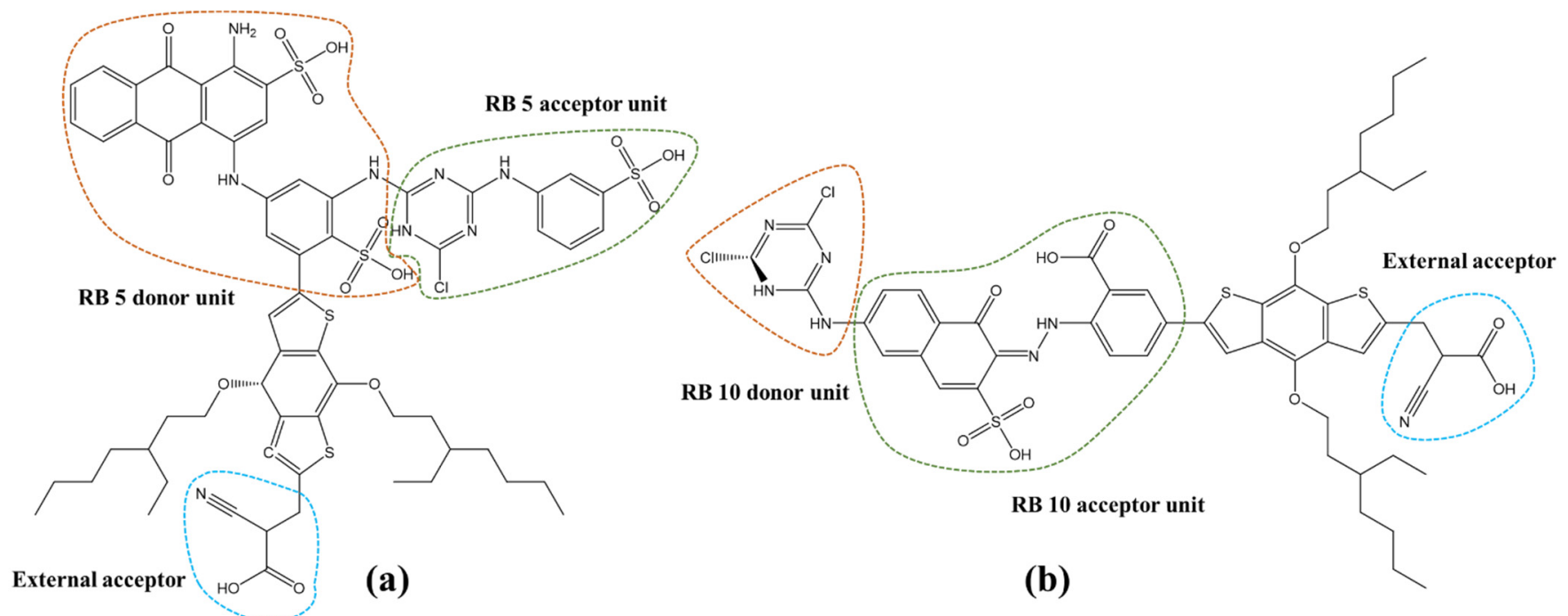

Figure 2. Introduction of the BDTA spacer and acceptor externally in (a) RB 5 and (b) RB 10 dye.

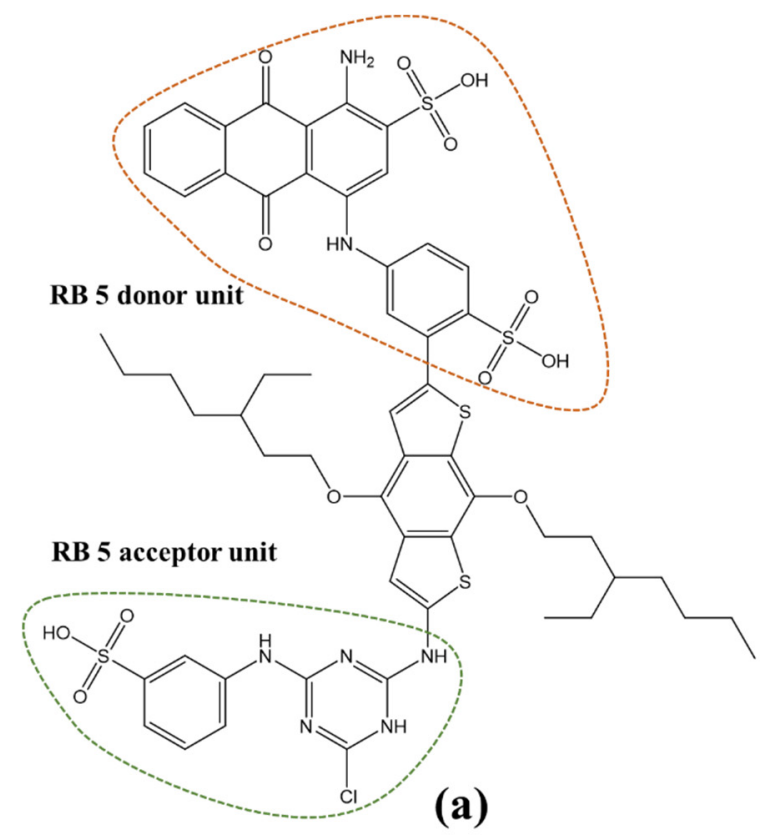

(a)

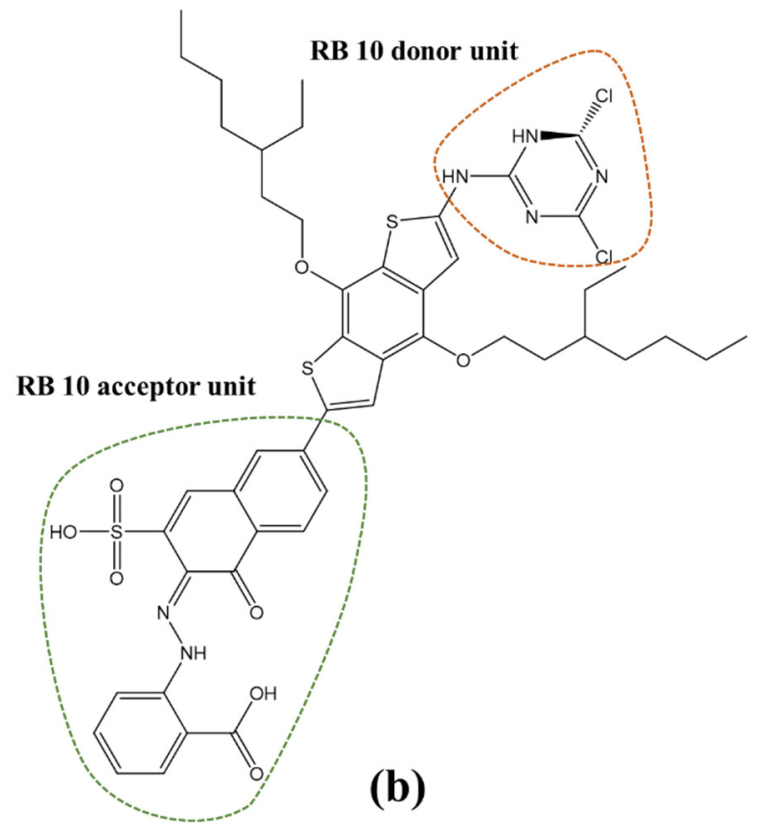

(b)

Figure 3. Introduction of the BDTA spacer between the intramolecular donor and acceptor units of (a) RB 5 and (b) RB 10 dye.

The reactive Dye-based sensitizers were obtained by the functional modification of dyes (RB 5-Et, RB 5- $\mathrm{NO}_{2}, \mathrm{RB} 10-\mathrm{Et}$, and RB 10-NO ${ }_{2}$ ) and by the introduction of BDTA $\pi$ spacer to form a donor- $\pi$-acceptor type system (RB 5-BDTA, RB 5-BDTA-A, RB 10-BDTA, and RB 10-BDTA-A). These modified molecules were compared using the DFT studies to determine the best suitable strategy.

\section{Results and Discussion}

\subsection{Modified Reactive Blue 5 as a Dye Sensitizer}

The DFT optimized geometries of the RB 5, RB 5-Et, RB 5- $\mathrm{NO}_{2}, \mathrm{RB} 5-\mathrm{BDTA}$, and RB 5-BDTA-A dye sensitizers are shown in Figure 4. The non-planar geometry of these molecules arose due to the non-zero dihedral angle. All the RB 5 Dye-based sensitizers showed the presence of a hydrogen bond between the $\mathrm{H}$ atom of the $-\mathrm{NH}$ group and the electronegative $\mathrm{O}$ atom of the $-\mathrm{SO}_{3} \mathrm{H}$ group that resided in its close vicinity. In the case 
of $\mathrm{RB} 5-\mathrm{NO}_{2}$, the $-\mathrm{SO}_{3} \mathrm{H}$ on the adjacent ring underwent free rotation and was hydrogenbonded to the $\mathrm{O}$ atom of the $-\mathrm{NO}_{2}$ group (Figure 4c). The alkyl chain of BDTA in RB 5-BDTA and RB 5-BDTA-A forced the aromatic rings of the dye to go out of a plane to achieve a geometry of minimum energy (Figure $4 \mathrm{~d}$,e). This led to increased $\mathrm{H}$-bondings as the atoms showing $\mathrm{H}$-bonding came closer. The carbon atoms in the alkyl chain of the BDTA were in their preferred staggered conformation, which maximized the distance between the repulsive bonding pairs. The staggered conformation indicated the possibility of active hyperconjugation effects in the alkyl chain that stabilizes the staggered conformation [64].
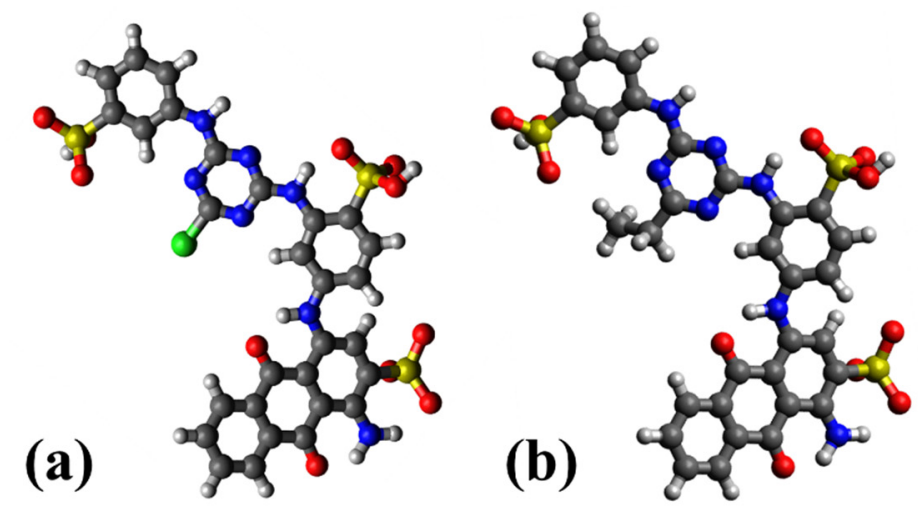

(c)
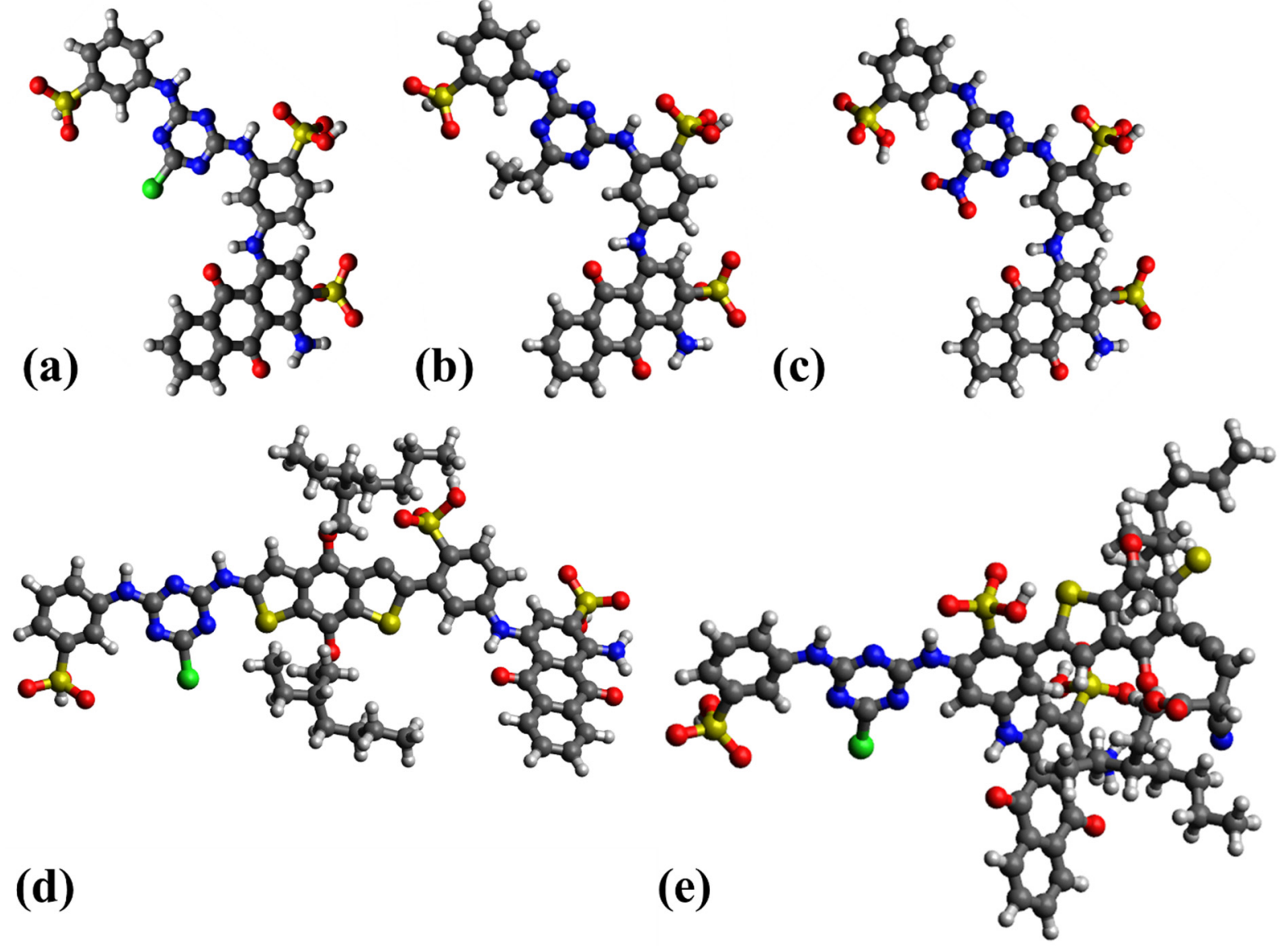

(d)

Figure 4. DFT optimized geometries of (a) RB 5, (b) RB 5-Et, (c) RB 5- $\mathrm{NO}_{2}$ (d) RB 5-BDTA, and (e) RB 5-BDTA-A dye sensitizers. (Red-O, Yellow-S, Green-Cl, Blue-N, Grey-C, White-H).

The electrostatic potential maps were evaluated to determine the charge distribution in the RB 5 Dye-based sensitizers (Figure 5). The red color denotes the electronegative potential site, and the blue color indicates the potential electropositive site. The $-\mathrm{SO}_{3} \mathrm{H}$ groups showed a substantial charge accretion in the RB 5 molecule and the modified RB 5 sensitizers (RB 5-Et, RB 5- $\mathrm{NO}_{2}$, RB 5-BDTA, and RB 5-BDTA-A). The aromatic rings were in the charge depleted regions in RB 5 and RB 5 modified with Et and $\mathrm{NO}_{2}$. Overall, the charge localized regions were visible in the RB 5, RB 5-Et, and $\mathrm{RB} 5-\mathrm{NO}_{2}$ dye sensitizers. After introducing the BDTA $\pi$-spacer, the charge distribution changed in RB 5-BDTA and RB 5-BDTA-A resulting, in a shift towards the $\pi$-donor junction. The charge accretion was observed near the carbon atoms of the BDTA $\pi$-spacer and supports the fact that alkyl groups exhibit an electron-donating tendency. This shift of the charge density towards the $\pi$-donor junction indicated that introducing a $\pi$-spacer either internally or externally facilitated the donor-acceptor charge transport compared to the -Et and $-\mathrm{NO}_{2}$-modified RB 5 dye sensitizers. The improved donor to acceptor charge transport made RB 5-BDTA and RB 5-BDTA-A suitable for an efficient DSSC system. 

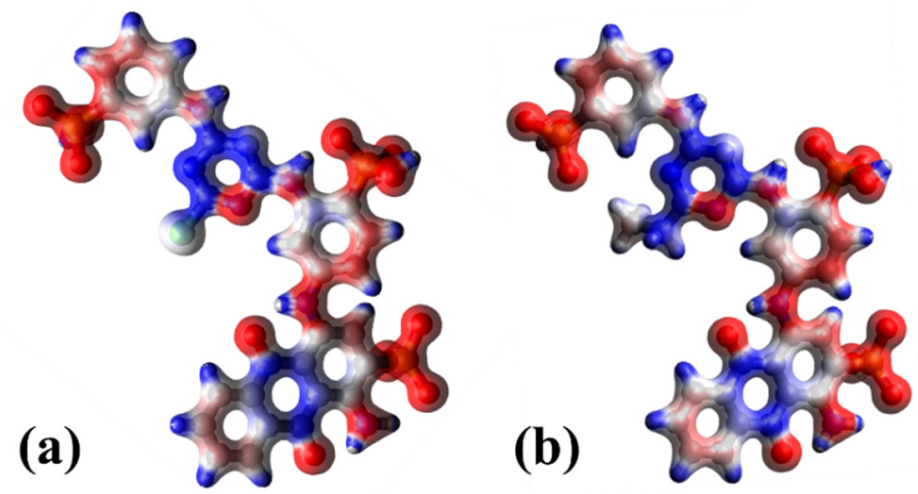

(c)
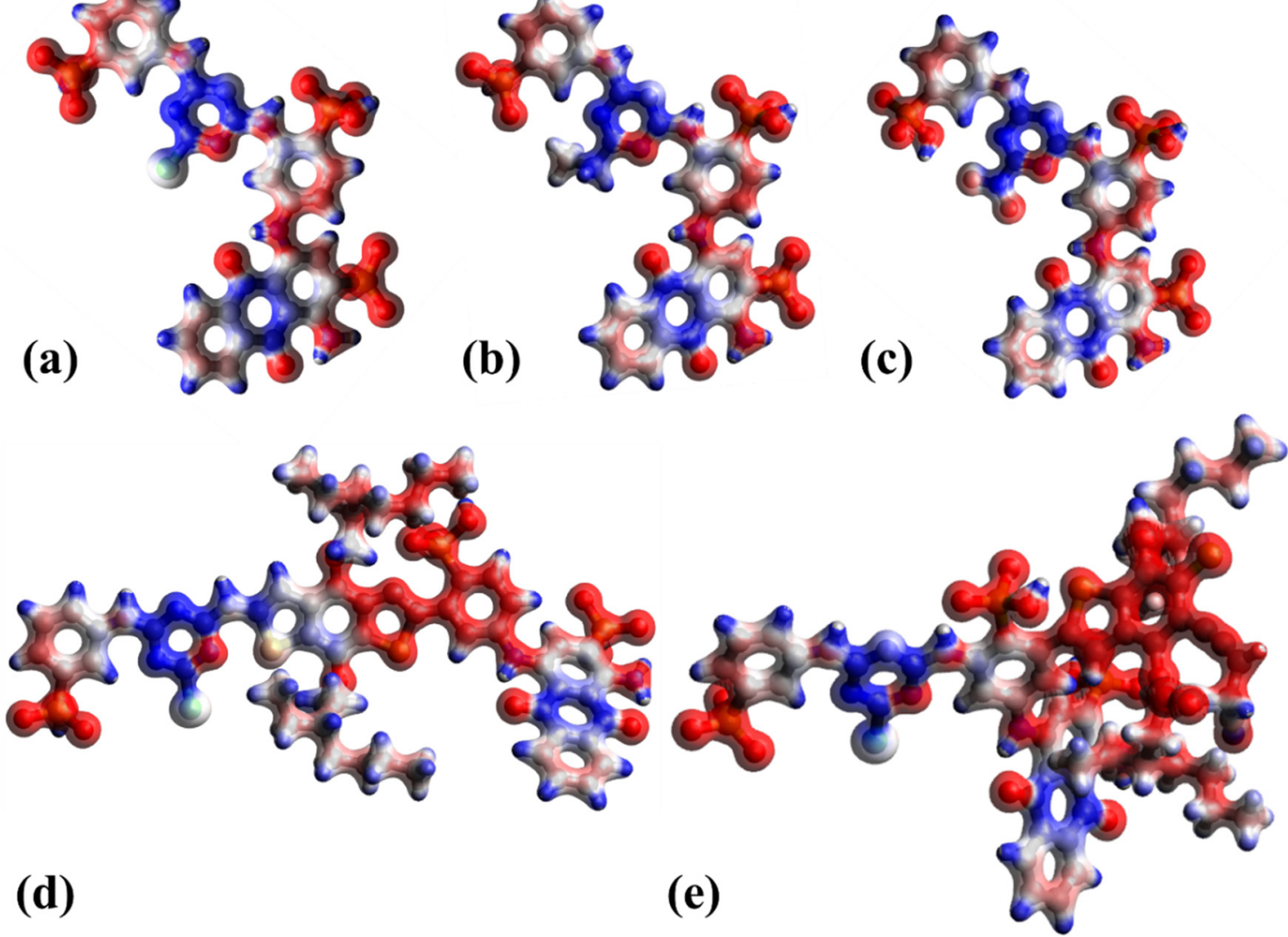

(d)

Figure 5. Electrostatic potential maps for optimized geometries of (a) RB 5, (b) RB 5-Et, (c) $\mathrm{RB} 5-\mathrm{NO}_{2}$, (d) RB 5-BDTA, and (e) RB 5-BDTA-A dye sensitizers. (Iso-value: 0.1).

Figure 6 shows the electron localization function for the optimized geometries of RB 5, RB 5-Et, RB 5-NO ${ }_{2}$, RB 5-BDTA, and RB 5-BDTA-A dye sensitizers. The electron density on the triazine ring was low, while the localization of electrons was higher on the atoms belonging to the donor unit, especially the $-\mathrm{SO}_{3} \mathrm{H}$ group. This was true for all the modified RB 5 dye sensitizers. This was in accordance with the results from the previous results.

The ground state HOMO-LUMO energies and the HLG values of the RB 5-based studied dye sensitizers (RB 5-Et, $\mathrm{RB} 5-\mathrm{NO}_{2}$, RB 5-BDTA, and RB 5-BDTA-A) are reported in Table 1. The effect of the $-\mathrm{NO}_{2}$ and -Et groups on the HLG value of RB 5 was not prominent because of their inability to influence the large RB 5 structure. The $-\mathrm{NO}_{2}$ group, being an electron-withdrawing group, reduced the electron density on the RB 5 dye sensitizer. Whereas the -Et group, being an electron-donating group, enhanced the electron transport. This was in accordance with the above results. Hence, substitution by electron-donating groups at the donor unit is favorable. RB 5-BDTA-A possessed the lowest value of HLG, i.e., $1.60 \mathrm{eV}$. The highest destabilization of the HOMO energy level for RB 5-BDTA led to the lowest HLG value [65]. Conversely, $\mathrm{RB} 5-\mathrm{NO}_{2}$ exhibited the highest value of HLG $(2.30 \mathrm{eV})$. This was attributed to the highest destabilization of LUMO energy levels. Thus, it was inferred that RB 5-BDTA-A showed better electron transportability. 
(a)

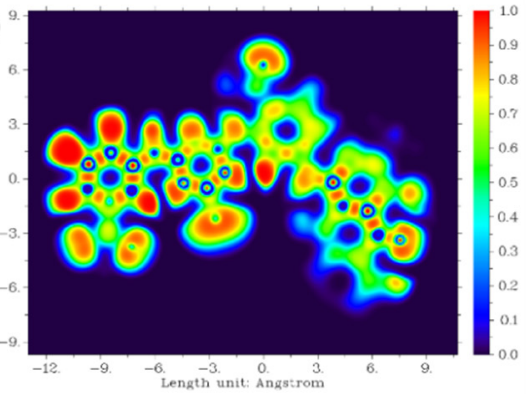

(d) (b)

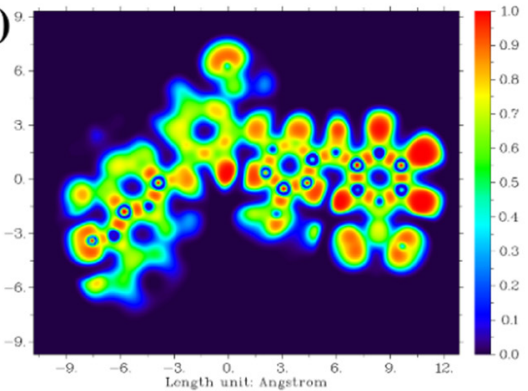

(c)

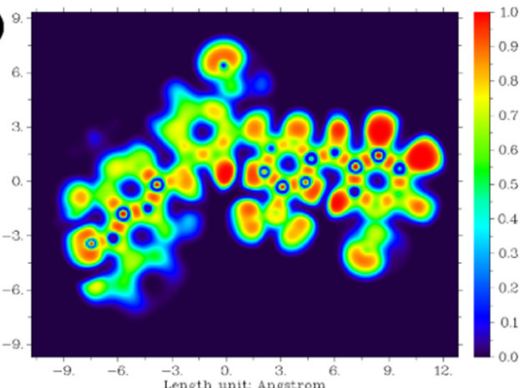

(e)

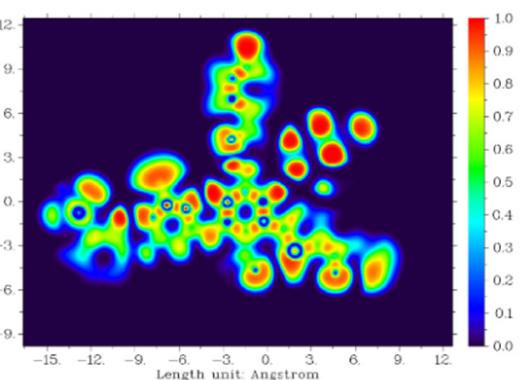

Figure 6. Electron localization function maps for optimized geometries of (a) RB 5 (b) RB 5-Et, (c) RB 5-NO ${ }_{2}$, (d) RB 5-BDTA, and (e) RB 5-BDTA-A dye sensitizers.

Table 1. The HOMO-LUMO energies and the HLG value of RB 5, RB 5-Et, RB 5- $\mathrm{NO}_{2}$, and (e) RB 5-BDTA dye sensitizers.

\begin{tabular}{cccccc}
\hline & RB 5 & RB 5-Et & RB 5-NO & RB 5-BDTA & RB 5-BDTA-A \\
\hline $\begin{array}{c}\text { HOMO } \\
(\mathrm{eV})\end{array}$ & -5.71 & -5.64 & -5.76 & -5.26 & -5.61 \\
\hline $\begin{array}{c}\text { LUMO } \\
(\mathrm{eV})\end{array}$ & -3.43 & -3.39 & -3.46 & -3.48 & -4.01 \\
\hline $\begin{array}{c}\text { HLG } \\
(\mathrm{eV})\end{array}$ & 2.28 & 2.25 & 2.30 & 1.78 & 1.60 \\
\hline
\end{tabular}

The HOMO-LUMO distribution on the optimized RB 5, RB 5-Et, RB 5- $\mathrm{NO}_{2}$, RB 5BDTA, and RB 5-BDTA-A dye sensitizer structures are presented in Figure 7. The HOMOs of the RB 5, RB 5-Et, and RB 5- $\mathrm{NO}_{2}$ dye sensitizers were localized over two of the three fused aromatic rings of RB 5 dye. The LUMOs of the RB 5, RB 5-Et, and $\mathrm{RB} 5-\mathrm{NO}_{2}$ dye sensitizers were localized on the remaining tailing end of the RB 5 moiety with a small degree of delocalization where the aromatic rings are fused. In the case of the RB 5-BDTA, the HOMOs were distributed over the donor unit, and the LUMOs resided on the BDTA $\pi$-spacer. The HOMO-LUMO of the RB 5-BDTA-A resided mainly near the donor-acceptor region.

Figure 8 shows the theoretically calculated FT-IR spectra of the RB 5, RB 5-Et, RB $5-\mathrm{NO}_{2}$, and RB 5-BDTA dye sensitizers. The IR spectra of RB 5 showed a strong stretching at $1520 \mathrm{~cm}^{-1}$ due to the aromatic rings. The bands at 1672 and $3045 \mathrm{~cm}^{-1}$ were attributed to the $-\mathrm{C}=\mathrm{O}$ and $=\mathrm{C}-\mathrm{H}$ stretching vibrations, respectively. The $\mathrm{C}-\mathrm{N}$ stretching vibrations were observed at $1235 \mathrm{~cm}^{-1}$. The IR spectra for RB 5-Et, RB 5-NO , and RB 5-BDTA showed similar spectra. However, the intensity of peaks between 1500 and $1550 \mathrm{~cm}^{-1}$ increased due to $-\mathrm{NO}_{2}$ stretching in the spectra of $\mathrm{RB} 5-\mathrm{NO}_{2}$. Additional bands appeared in the IR spectra RB 5-BDTA-A. A very weak band at $2230 \mathrm{~cm}^{-1}$ appeared due to the nitrile stretching. An olefinic carbon of cyanoacrylic acid showed a band at $3090 \mathrm{~cm}^{-1}$ due to the olefinic $-\mathrm{C}-\mathrm{H}$ stretching. In RB 5-BDTA-A, the $\mathrm{C}-\mathrm{H}$ stretching peaks were more profound. 
(a)
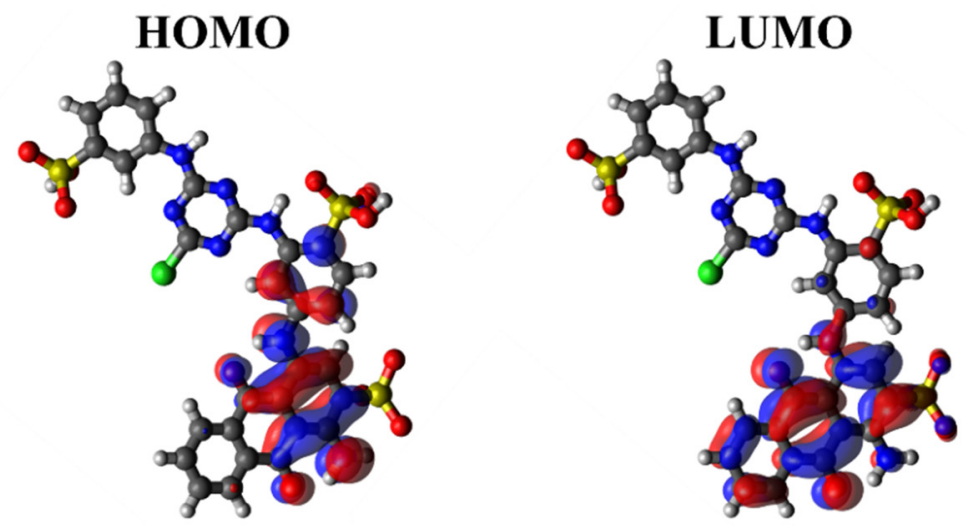

(b)
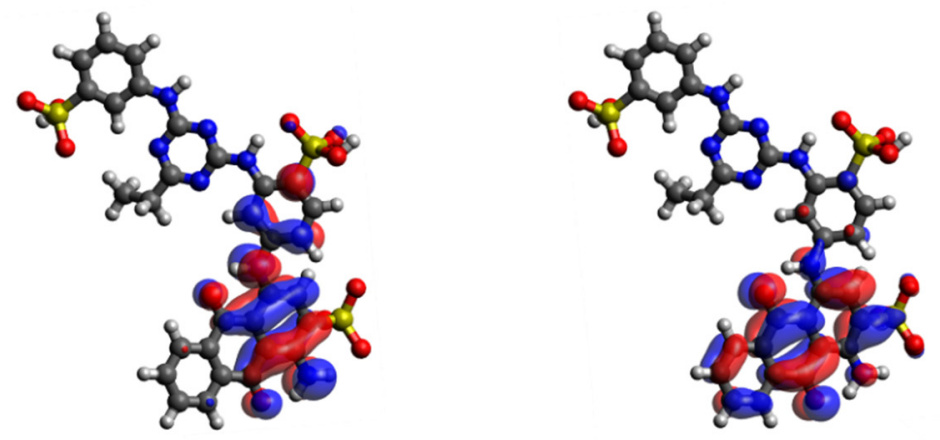

(c)
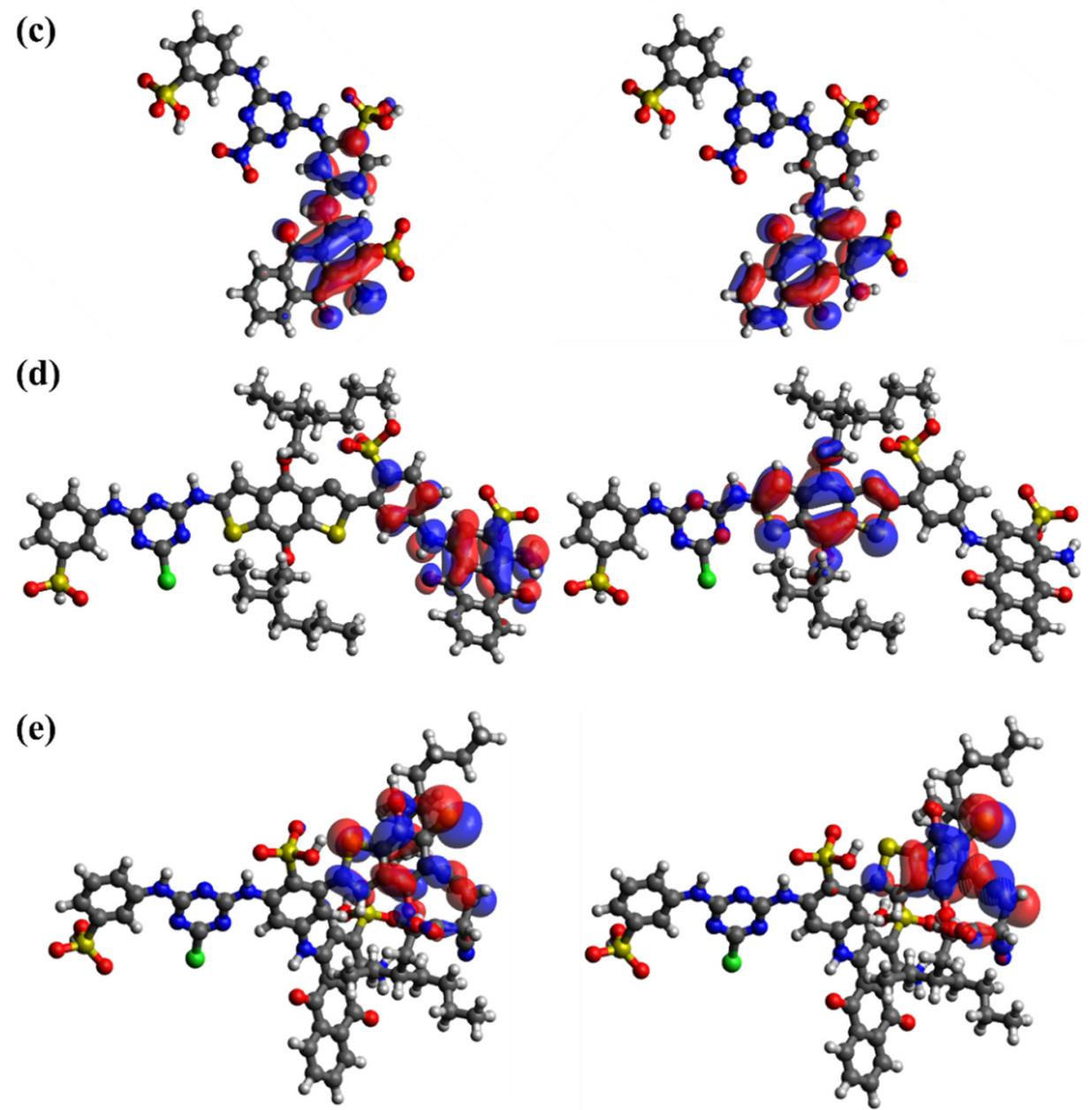

Figure 7. The HOMO-LUMO distributions for optimized geometries of (a) RB 5 (b) RB 5-Et, (c) RB 5- $\mathrm{NO}_{2}$, (d) RB 5-BDTA, and (e) RB 5-BDTA-A. (Iso-value: 0.02). 


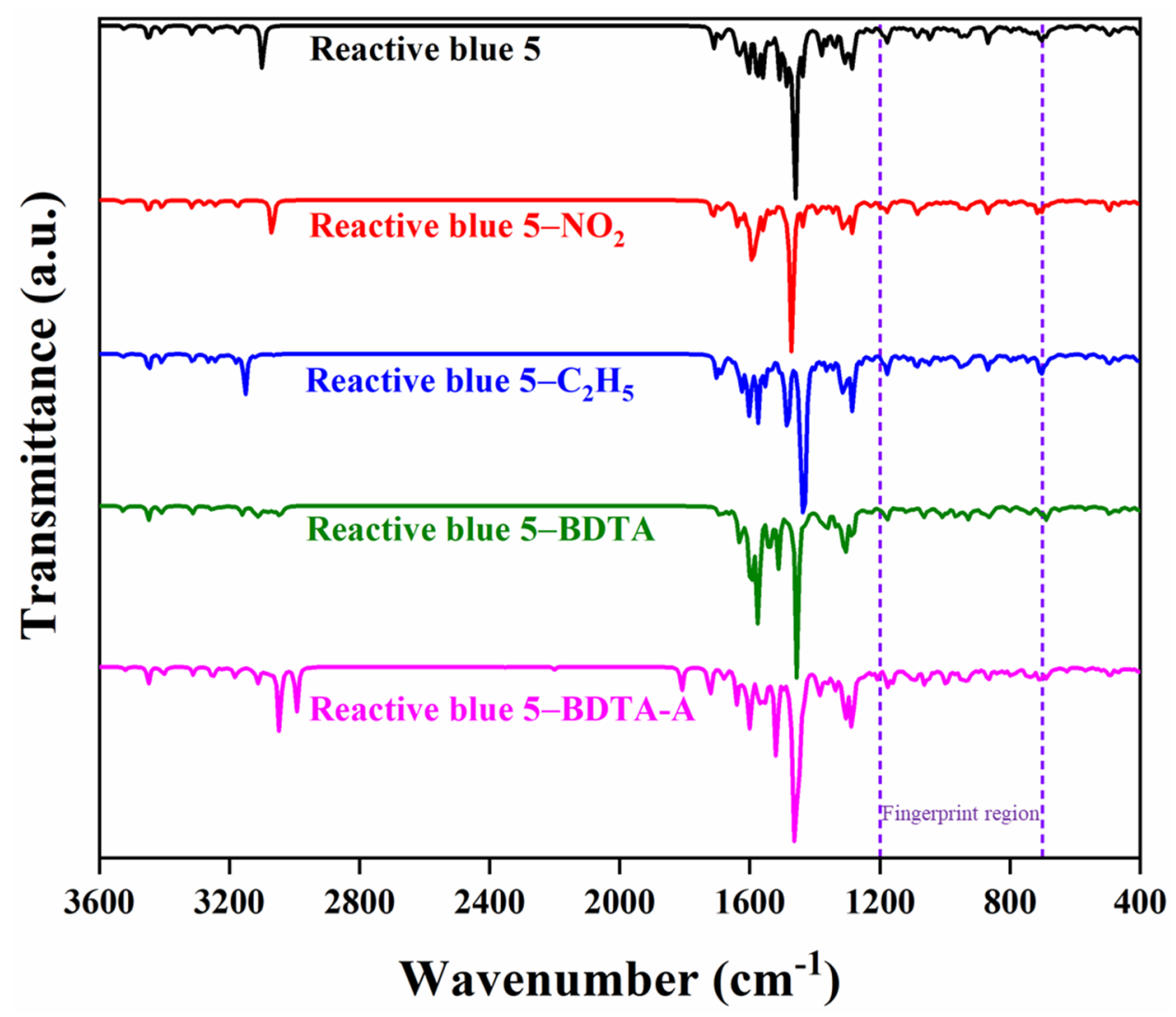

Figure 8. Theoretically obtained FT-IR spectra of RB 5, RB 5-Et, RB 5-NO $\mathrm{NO}_{2}$ RB 5-BDTA, and RB 5-BDTA-A dye sensitizers.

The DOS plot of RB 5, RB 5-Et, RB 5- $\mathrm{NO}_{2}, \mathrm{RB}$ 5-BDTA, and RB 5-BDTA-A are depicted in Figure 9. The donor units in both the donor- $\pi$-acceptor concept-based designs offered a maximum contribution to the frontier molecular orbital in all the investigated RB 5 -based dye sensitizers. The bandgaps obtained from the DOS revealed that among RB 5, RB 5-Et, RB 5- $\mathrm{NO}_{2}$, RB 5-BDTA, and RB 5-BDTA-A dye sensitizers, the frontier molecular orbitals of RB 5-BDTA and RB 5-BDTA-A were closely spaced compared to others and favored the effective electron injection. This is in good agreement with the HOMO-LUMO distributions. Based on the DOS plots, it was inferred that after the introduction of BDTA (i.e., in RB 5-BDTA and RB 5-BDTA-A), the ability of the sensitizers increased as the HLG was small. A smaller HLG allows easy electron excitations and thus help in improving the efficiency of DSSC. Dyes with low HLG are preferred for DSSC applications [66]. Thus, these findings can be used to extend the application of reactive dyes for DSSC applications. 

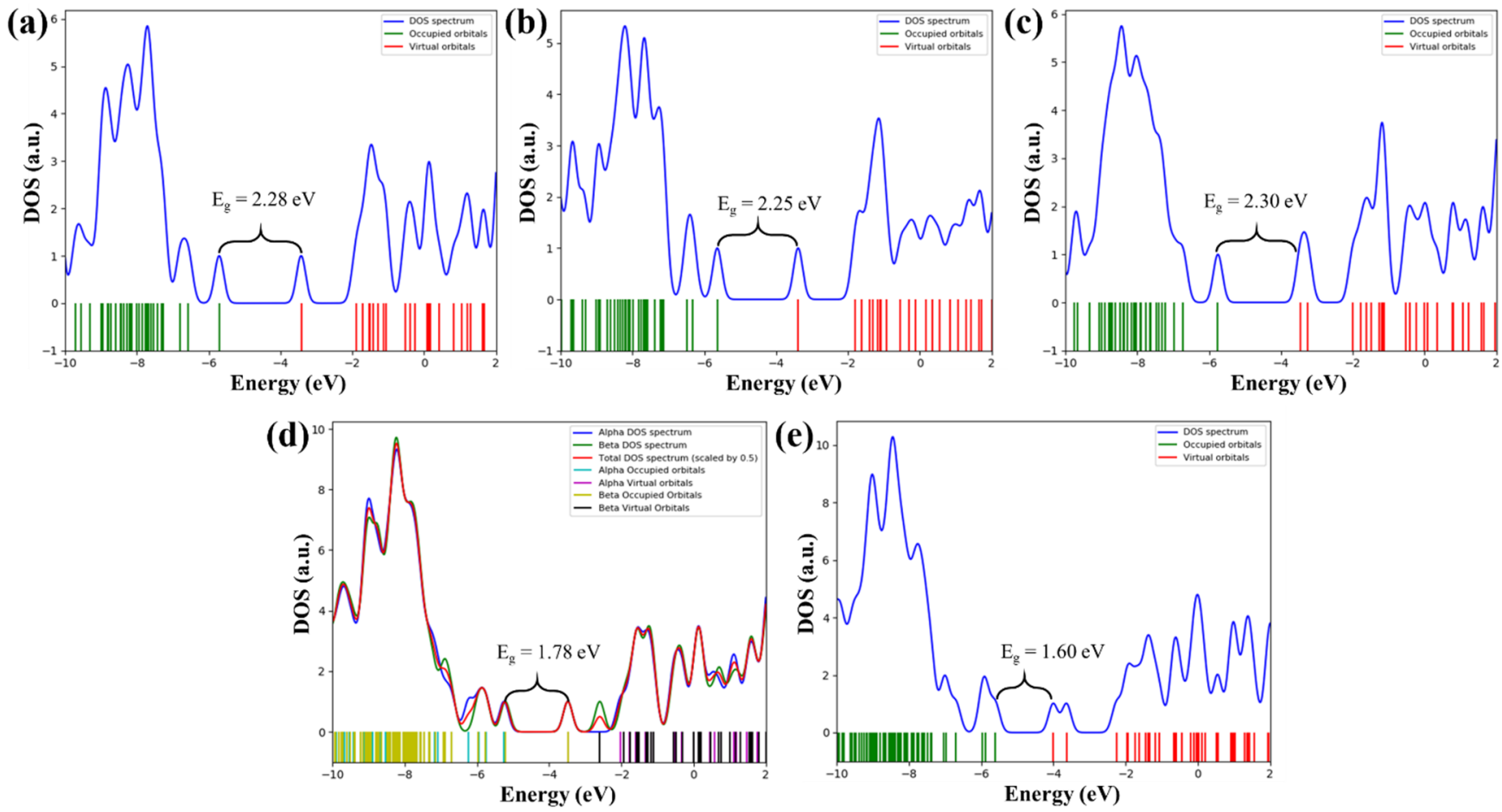

Figure 9. DOS plots of (a) RB 5, (b) RB 5-Et, (c) RB 5-NO2, (d) RB 5-BDTA, and (e) RB 5-BDTA-A dye sensitizers.

\subsection{Modified Reactive Brown 10 as Dye Sensitizer}

The DFT optimized geometries of the RB 10, RB 10-Et, RB 10-NO $\mathrm{NO}_{2}$ RB 10-BDTA, and RB 10-BDTA-A structures are shown in Figure 10. The RB 10, RB 10-Et, and RB 10-NO ${ }_{2}$ geometries were planar. Since the $-\mathrm{Et}$ and $-\mathrm{NO}_{2}$ groups were far apart from any other groups, no intramolecular interactions were seen in the RB 10-Et and RB 10- $\mathrm{NO}_{2}$ sensitizers. The RB 10-BDTA and RB 10-BDTA-A molecules exhibited a non-planar structure. The bulky alkyl substituent on the $\pi$-spacer was responsible for this deviation from the planar structure.

The electrostatic potential maps of the RB 10 Dye-based sensitizers (RB 10, RB 10-Et, RB 10- $\mathrm{NO}_{2}$, RB 10-BDTA, and RB 10-BDTA-A) are shown in Figure 11. The red color denotes the electronegative potential site, and the blue color denotes the electropositive potential site. The triazine ring was in the electron depletion region. In contrast, the two fused benzylic rings and the $-\mathrm{COOH}$ substituted benzene ring linked by an $\mathrm{N}-\mathrm{N}$ linkage were in the negative electrostatic potential region. A slight rise in the charge accretion was observed near the $\pi$-donor unit junction in RB 10-BDTA and RB 10-BDTA-A dye sensitizers, indicating electron transport facilitation through the $\pi$-spacer. The carbon atoms of the alkyl chain attached to the $\pi$-spacer showed charge accretion. The RB 10-BDTA molecule showed the possibility of electron transport, unlike RB 10, RB 10-Et, and RB $10-\mathrm{NO}_{2}$, where the charged regions were localized. In RB 10-BDTA-A, the shift towards the $\pi$-donor junction was observed. Thus, RB 10-BDTA-A exhibited a better efficiency than the other designs, attributed to the strong electron-withdrawing group in the acceptor unit.

Figure 12 shows the electron localization function of the RB 10, RB 10-Et, RB 10- $\mathrm{NO}_{2}$, RB 10-BDTA, and RB 10-BDTA-A sensitizers. The electrons were localized mostly at the donor unit, whereas the acceptor triazine unit showed less electron localization. 

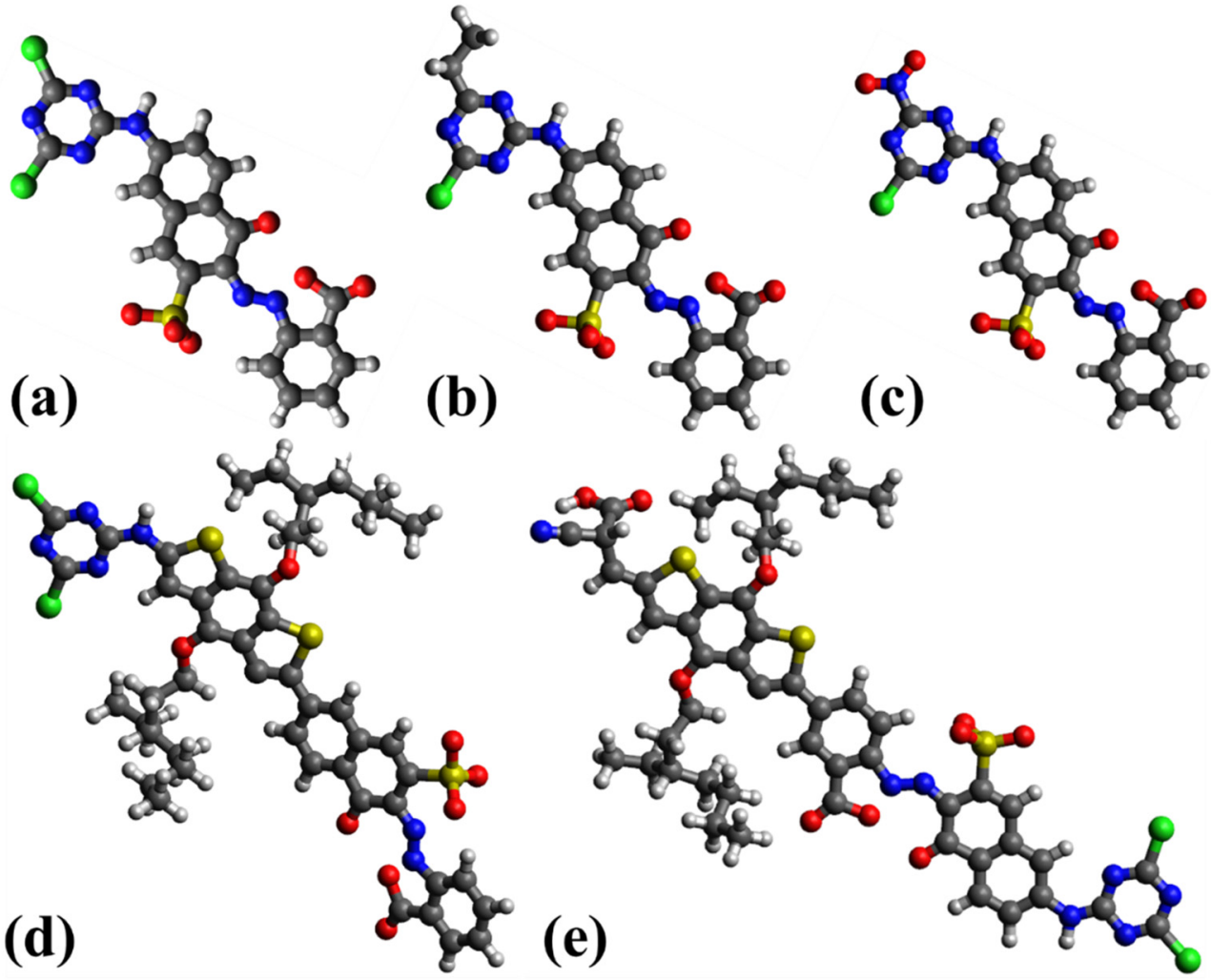

Figure 10. DFT optimized geometries of (a) RB 10, (b) RB 10-Et, (c) RB 10-NO (e) RB 10-BDTA-A dye sensitizers. (Red-O, Yellow-S, Green-Cl, Blue-N, Grey-C, White-H).
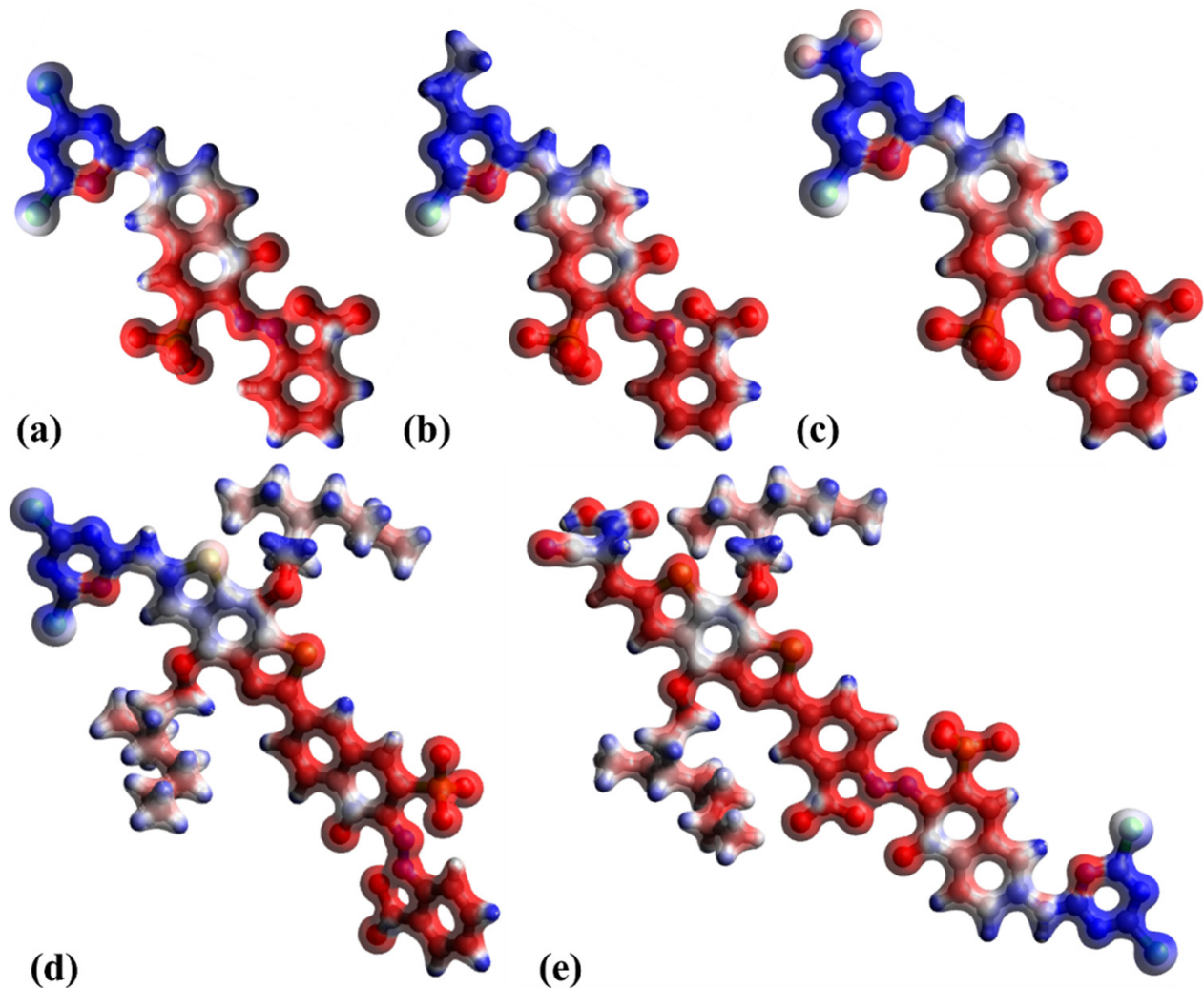

Figure 11. Electrostatic potential maps for the optimized geometries of (a) RB 10, (b) RB 10-Et, (c) RB 10- $\mathrm{NO}_{2}$, (d) RB 10-BDTA, and (e) RB 10-BDTA-A dye sensitizers. (Iso-value: 0.1). 

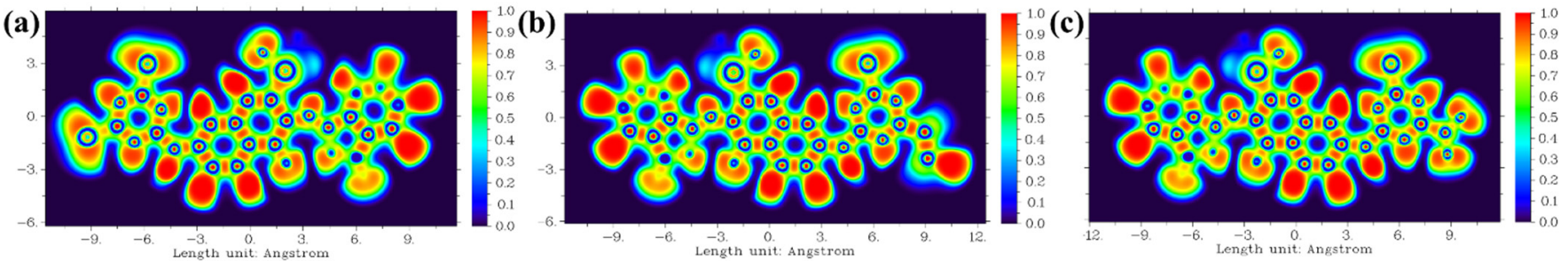

(d)
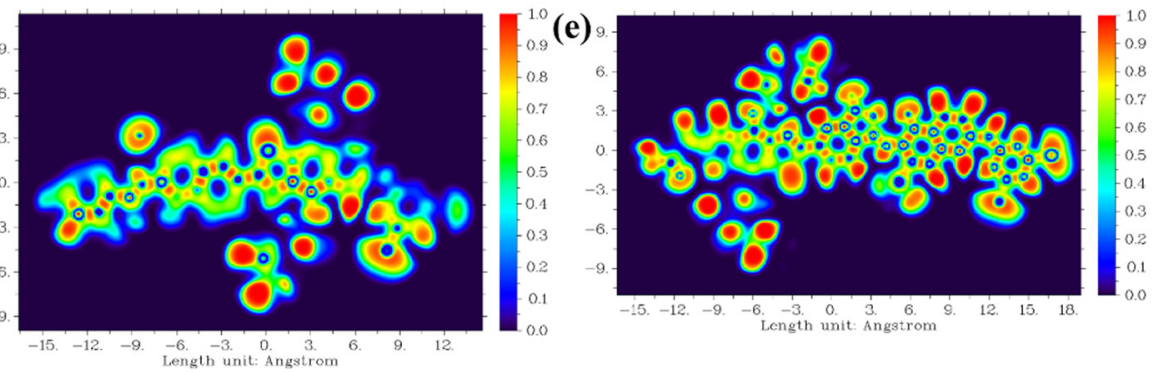

Figure 12. Electron localization function maps for the optimized geometries of (a) RB 10, (b) RB 10-Et, (c) RB 10- $\mathrm{NO}_{2}$, (d) RB 10-BDTA, and (e) RB 10-BDTA-A dye sensitizers.

The ground state HOMO-LUMO energies and the HLG values of RB 10, RB 10-Et, RB 10- $\mathrm{NO}_{2}, \mathrm{RB} 10-\mathrm{BDTA}$, and RB 10-BDTA-A are reported in Table 2. The lowest value of HLG, i.e., $0.25 \mathrm{eV}$, corresponds to the RB 10-BDTA-A dye sensitizer. The RB 10-BDTA-A dye sensitizer showed the highest destabilization of the HOMO energy level, attributed to the lowest $\mathrm{HLG}$ value. The presence of the $-\mathrm{Et}$ and $-\mathrm{NO}_{2}$ groups on the triazine ring (acceptor) in RB 10-Et and RB 10- $\mathrm{NO}_{2}$, dye sensitizers, respectively, led to an opposite effect of the substituent wherein the $-\mathrm{NO}_{2}$ (an electron-withdrawing group) showed a decrease (of $0.09 \mathrm{eV}$ ), whereas the -Et (an electron-donating group) brought about an increase of $0.02 \mathrm{eV}$ in the bandgap. Thus, RB 10-Et exhibited the highest value of HLG in agreement with the highest destabilization of its LUMO energy levels. It was thus inferred based on the HLG value that the ease of electron transportability was at a maximum in the RB 10-BDTA-A dye sensitizer.

Table 2. The HOMO-LUMO energies and the HLG value of RB10, RB10-Et, RB10-NO ${ }_{2}$, and RB10BDTA dye sensitizers.

\begin{tabular}{cccccc}
\hline & RB 10 & RB 10-Et & RB 10-NO & RB 10-BDTA & RB 10-BDTA-A \\
\hline $\begin{array}{c}\text { HOMO } \\
(\mathrm{eV})\end{array}$ & -6.50 & -6.36 & -6.58 & -5.57 & -5.29 \\
\hline $\begin{array}{c}\text { LUMO } \\
(\mathrm{eV})\end{array}$ & -3.49 & -3.33 & -3.66 & -5.22 & -5.04 \\
\hline $\begin{array}{c}\mathrm{HLG} \\
(\mathrm{eV})\end{array}$ & 3.01 & 3.03 & 2.92 & 0.35 & 0.25 \\
\hline
\end{tabular}

The HOMO-LUMO distributions on the optimized RB 10, RB 10-Et, RB 10- $\mathrm{NO}_{2}$, RB 10-BDTA, and RB 10-BDTA-A structures are shown in Figure 13. The $\pi$ molecular orbitals were distributed over the central benzylic rings in RB 10, RB 10-Et, and RB 10$\mathrm{NO}_{2}$ structures, whereas the LUMOs were delocalized more on the $-\mathrm{C}=\mathrm{O}$ and $-\mathrm{C}(\mathrm{O}) \mathrm{OH}$ substituted aromatic rings. The HOMOs and the LUMOS of RB 10-BDTA and RB 10-BDTAA were distributed over the donor- $\pi$ units. Additionally, the $\mathrm{S}$ atom of $-\mathrm{SO}_{3} \mathrm{H}$ had $\mathrm{HOMO}$ orbitals, whereas the LUMO orbitals resided on the neighboring $\mathrm{O}$ atoms in RB 10-BDTA. 
(a)

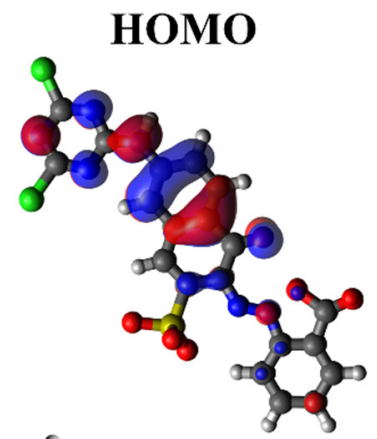

(c)

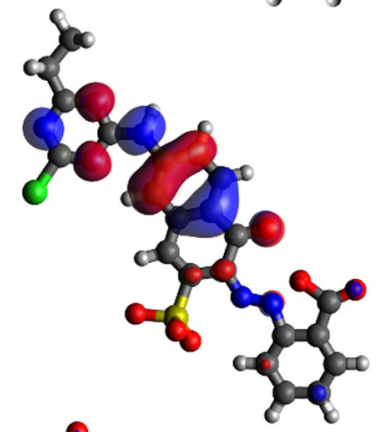

(d)

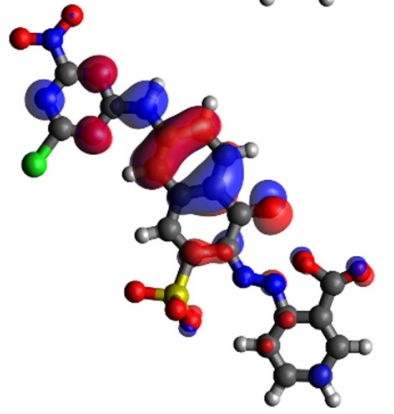

\section{LUMO}
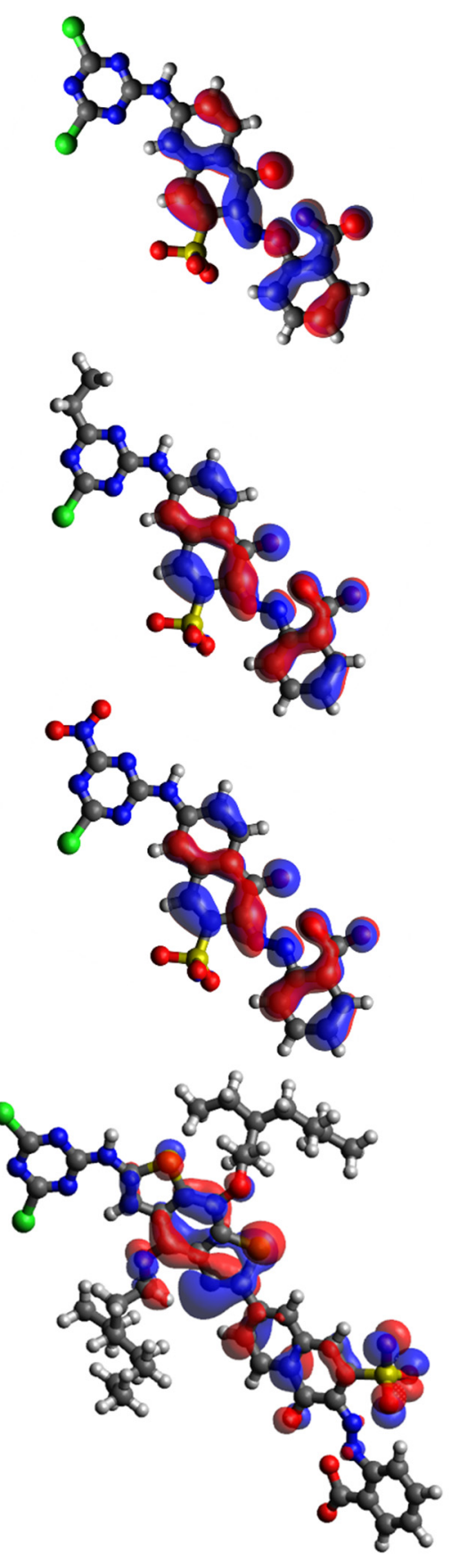

(e)

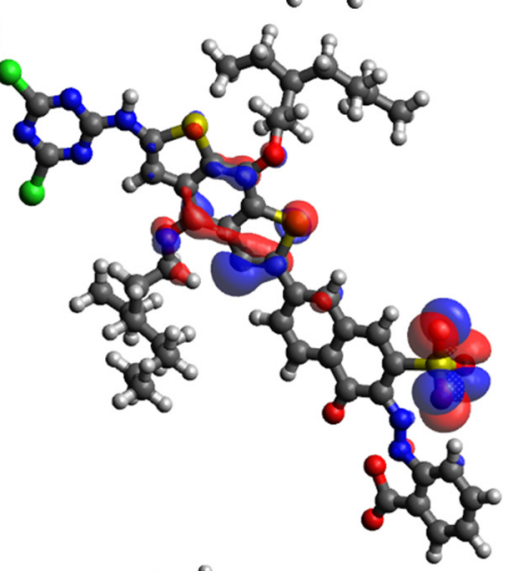

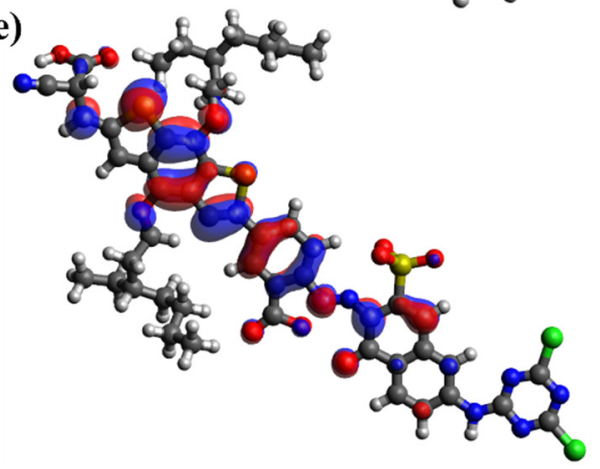

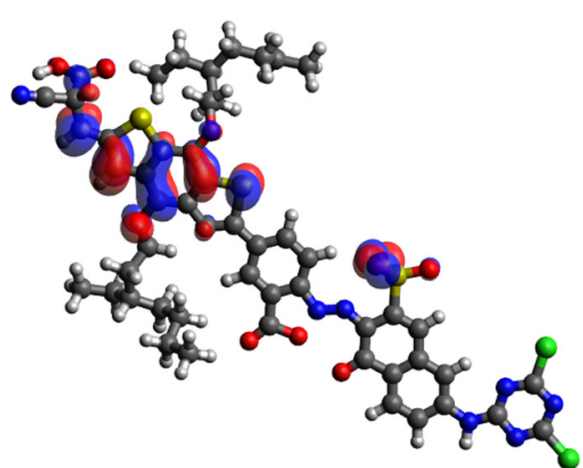

Figure 13. The HOMO-LUMO distributions of (a) RB 10, (b) RB 10-Et, (c) $\mathrm{RB} 10-\mathrm{NO}_{2}$, (d) RB 10-BDTA, and (e) RB 10-BDTA-A dye sensitizers. (Iso-value: 0.02). 
Figure 14 represents the theoretically calculated FT-IR spectra of the RB 10, RB 10-Et, RB 10- $\mathrm{NO}_{2}$, RB 10-BDTA, and RB 10-BDTA-A dye sensitizers. RB 10 dye showed a strong stretching due to the aromatic $-\mathrm{C}-\mathrm{H}$ group at $1520 \mathrm{~cm}^{-1}$. A carbonyl $(\mathrm{C}=\mathrm{O})$ stretching was observed at $1680 \mathrm{~cm}^{-1}$ and a $\mathrm{C}-\mathrm{O}$ stretching at $1790 \mathrm{~cm}^{-1}$. A small band due to $=\mathrm{C}-\mathrm{H}$ stretching vibrations appeared at $3037 \mathrm{~cm}^{-1}$. The vibrational band of $\mathrm{C}-\mathrm{N}$ stretching was observed at $1249 \mathrm{~cm}^{-1}$. The IR spectra for RB 10-Et, RB 10- $\mathrm{NO}_{2}$, and RB-BDTA showed a similarity. The band of $-\mathrm{NO}_{2}$ appeared in $\mathrm{RB} 5-\mathrm{NO}_{2}$ IR spectra, whereas the band due to the aromatic stretching intensified in the spectra of RB 5-BDTA. The band at $1075 \mathrm{~cm}^{-1}$ arose due to $\mathrm{C}-\mathrm{O}$ stretching of the vinyl ether in the IR spectra of RB 5-BDTA-A. Due to the striking geometrical transformation, the $\mathrm{C}-\mathrm{O}$ stretch was apparent. At $735 \mathrm{~cm}^{-1}$, a peak due to cis disubstituted $\mathrm{C}=\mathrm{C}$ was observed due to the olefinic carbons of the acceptor unit.

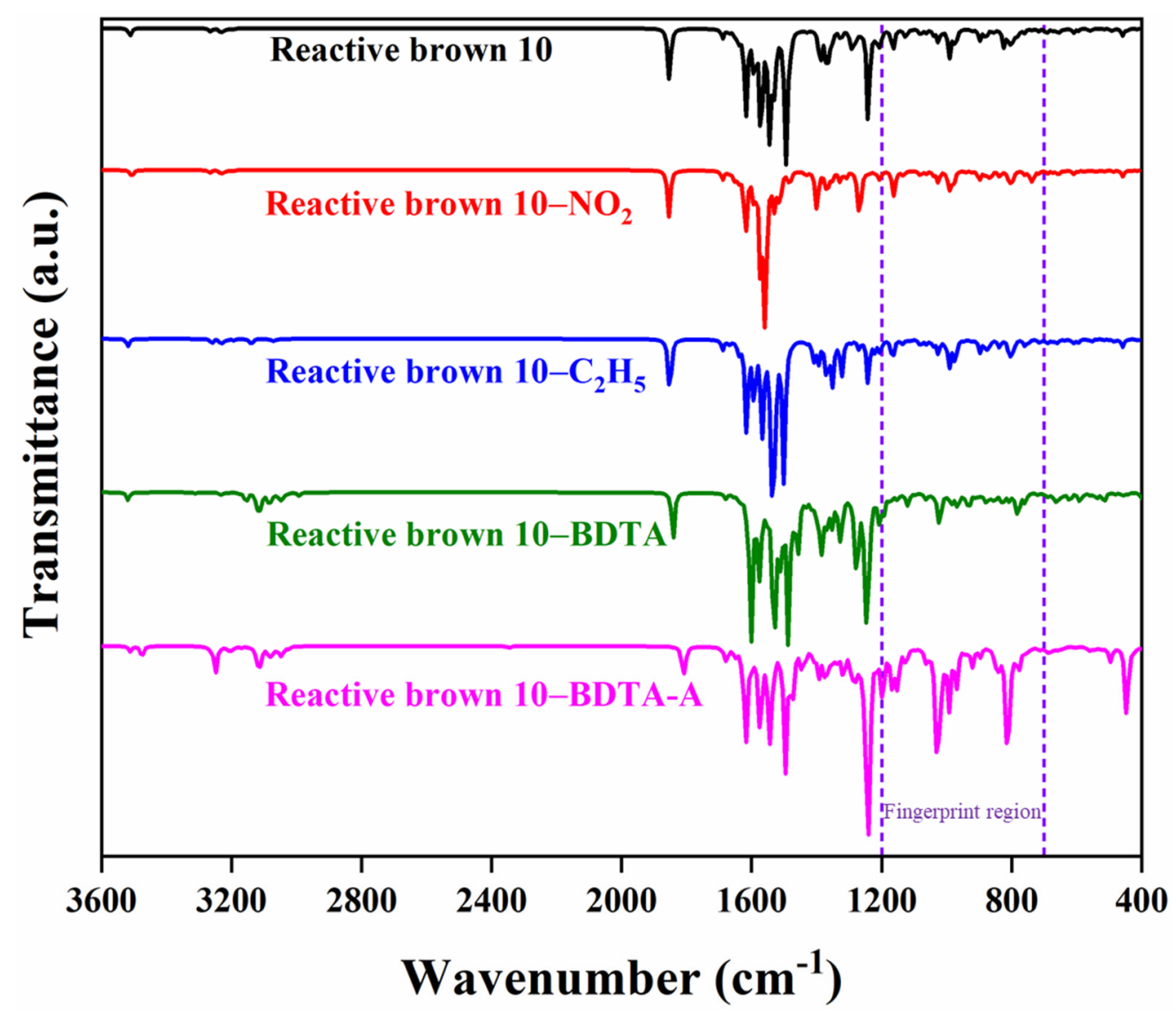

Figure 14. Theoretically obtained FT-IR spectra of RB 10, RB 10-Et, RB 10-NO 2 , RB 10-BDTA, and RB 10-BDTA-A dye sensitizers.

The DOS plots for the RB 10, RB 10-Et, RB 10-NO, RB 10-BDTA, and RB 10-BDTA-A sensitizers are depicted in Figure 15. The maximum contribution of the donor unit towards the HOMO-LUMO orbitals was observed in the RB 10-BDTA and RB 10-BDTA-A dye sensitizers. The bandgaps obtained from the DOS revealed that among RB 10, RB 10-Et, RB 10- $\mathrm{NO}_{2}, \mathrm{RB} 10-\mathrm{BDTA}$, and RB 10-BDTA-A, the frontier molecular orbitals of RB 10-BDTAA were closely spaced compared to others and favored the electron transport. This was in good agreement with the HOMO-LUMO distributions obtained in this study. The DOS analysis confirmed that the introduction of BDTA $\pi$-spacer reduced the HLG significantly. This was further lowered by attaching an acceptor unit to the dye molecule through the $\pi$-spacer. Hence, the $\pi$-spacer-based RB 10-BDTA and RB 10-BDTA-A sensitizers are expected to exhibit a better efficiency for DSSC applications. 

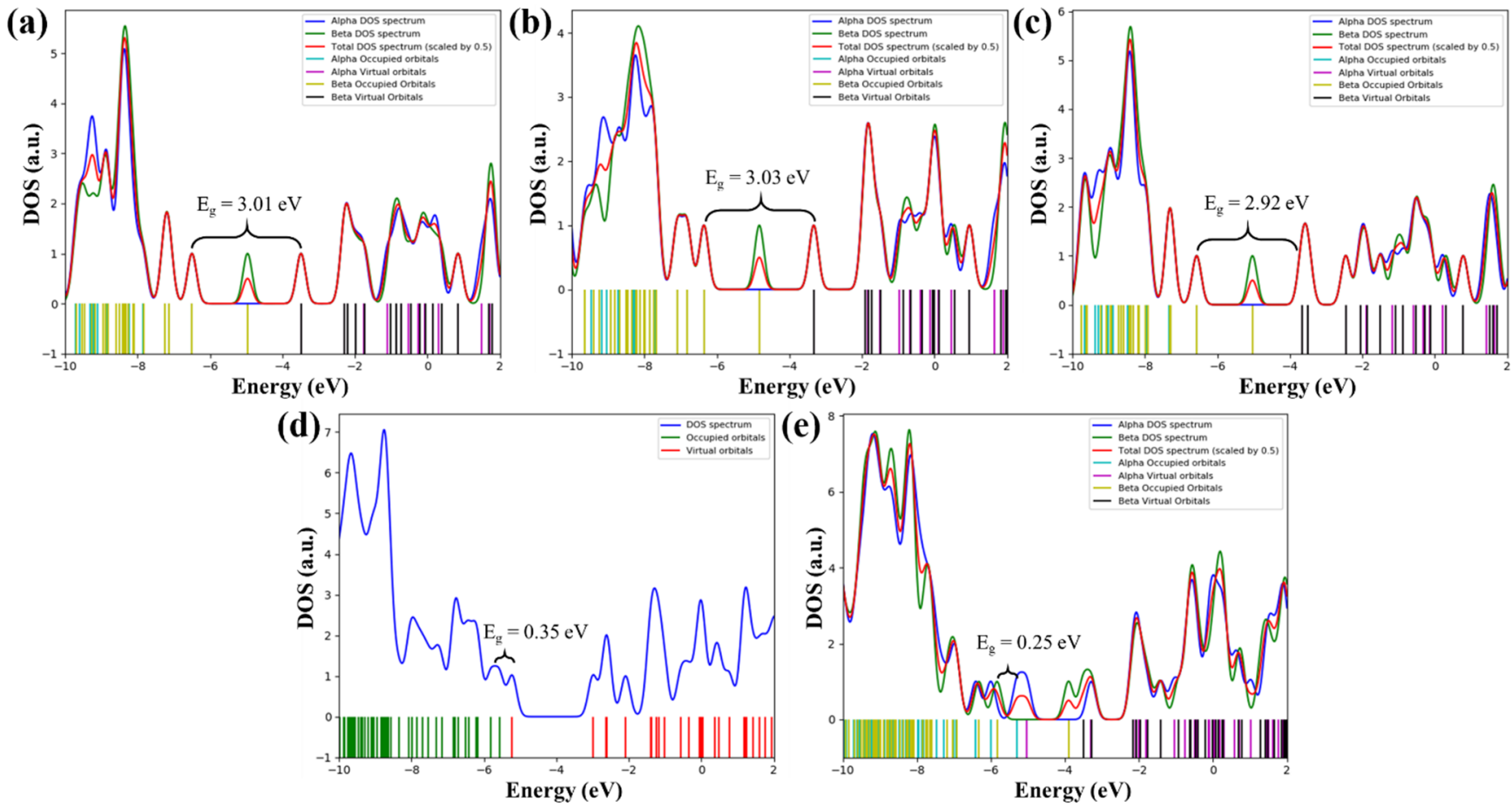

Figure 15. DOS plots of the (a) RB10, (b) RB10-Et, (c) RB10-NO $\mathrm{NO}_{2}$ (d) RB 10-BDTA, and (e) RB 10-BDTA-A dye sensitizers.

\subsection{Comparison of Modified Dyes}

The planarity of the dye sensitizers is a crucial factor influencing the efficiency of the DSSCs [65]. RB 5 and the modified RB 5-based dye sensitizers (RB 5, RB 5-Et, RB 5- $\mathrm{NO}_{2}$ ) showed a non-planar geometry, which reduced the conjugation in these systems. On the other hand, RB 10, RB 10-Et, and RB 10- $\mathrm{NO}_{2}$ structures were almost planar due to a small dihedral angle. This led to maximum conjugation in these structures. The structure with maximum conjugation leads to a better charge delocalization [36]. The donor- $\pi$-acceptor type sensitizers, namely RB 5-BDTA, RB 5-BDTA-A, RB 10-BDTA, and RB 10-BDTA$A$, exhibited a non-planar geometry because of the reduced degree of conjugation. The electrostatic potential maps revealed that in both the dye sensitizers (for all the cases), the triazine ring was in the electrostatic positive region and thus acted as a good acceptor. A shift of charge accretion was observed near the donor- $\pi$ junction in both RB 5-BDTA and RB 10-BDTA dye sensitizer molecules. The shift was more apparent when cyanoacrylic acid was used as the acceptor unit. This shift was linked to the electron-withdrawing capacity of the nitrile group. Moreover, the stabilization that resulted from the resonating structures acted as a driving force for the electron shift. This indicated the improved electronic transport properties in both types of donor- $\pi$-acceptor systems. The electron localization functions for all the systems were in agreement with those from the electrostatic potential maps. For a favorable electron injection, it is expected that the LUMO of the acceptor should be above the conduction band of the conducting oxide material. The LUMO energies of all the sensitizers were compared with a typical $\mathrm{TiO}_{2}$ oxide conduction band $(-4.2 \mathrm{eV})$ [67]. All the dye sensitizers except RB 10-BDTA and RB 10-BDTA-A had a LUMO placed at higher energy with respect to the conduction band of $\mathrm{TiO}_{2}$. Thus, compared to RB 10-BDTA and RB 10-BDTA-A, the electron injection was more feasible in other dye sensitizers. RB 5-BDTA-A and RB 10-BDTA-A showed the lowest HLG values among their respective group because of their highest destabilization of the HOMO energy level. The highest destabilization was observed in $\mathrm{RB} 5-\mathrm{NO}_{2}$ and $\mathrm{RB} 10-\mathrm{Et}$, leading to a maximum value of HLG.

The RB 10-BDTA-A sensitizer was adjudged with better electron injection performance based on the above results. The DOS plots showed that the donor unit contributed to a maximum extent in the frontier molecular orbitals of the RB 5-BDTA, RB 5-BDTA-A, RB 
10-BDTA, and RB 10-BDTA-A sensitizers. Moreover, the RB 10-BDTA-A showed better electronic transport properties. Collectively, based on the DFT calculations, it was inferred that the design based on the donor- $\pi$-acceptor strategy is effective for designing a DSSC using reactive dyes.

\section{Conclusions}

This study reports the first principle DFT investigation of the donor- $\pi$-acceptor type and functionally modified reactive dyes (RB 5 and RB 10) to improve their efficiency in designing an efficient sensitizer for DSSC application. Of the three design strategies used, the one based on the anchoring of functional groups (-Et and $-\mathrm{NO}_{2}$ ) on the dye molecule using synthetic transformation was unfavorable. The DFT investigation revealed no change in the electronic properties of the dye sensitizers. The effect was not apparent due to the small size of the $\mathrm{NO}_{2}$ and Et groups compared to the dye structures. A great improvement was observed in a donor- $\pi$-acceptor design where the results improved drastically. The electrostatic potential maps of the BDTA spacer-based sensitizers namely showed a shift in charge density near the donor- $\pi$ junction, indicating the better transportability of electrons. The electron localization function maps confirmed the observed shifts of charge densities from the electrostatic potential maps. The HLG reduced significantly from 2.28 to $1.60 \mathrm{eV}$ (for RB 5-BDTA-A) and from 3.01 to $0.25 \mathrm{eV}$ (for RB 10-BDTA-A) on using donor- $\pi$-acceptor implying a better electron injection efficiency. Despite the non-planar geometries of RB 5BDTA, RB 5-BDTA-A, RB 10-BDTA, and RB10-BDTA-A, the extent of conjugation reduced and the electronic properties improved in both cases due to the presence of a $\pi$-spacer.

The RB10-BDTA-A showed the best electron injection efficiency among all the studied sensitizers. The overall results showed that for designing a dye sensitizer from reactive dye, the donor- $\pi$-acceptor strategy is the most suitable one. Apart from this, the study also revealed that, when attaching an external $\pi$-spacer, the modifications can be made by identifying the intramolecular donor-acceptor regions. The intramolecular insertion of a $\pi$-spacer was found to produce comparable results to that of a conventional donor$\pi$-acceptor system. This study can further be extended for designing sensitizers with enhanced efficiency for the DSSC with greater ease of synthetic feasibility.

Author Contributions: Conceptualization, S.S.D. and A.Y.; methodology, S.S.D. and A.Y.; formal analysis, S.S.D. and A.Y.; resources, A.Y.; data curation, S.S.D. and A.Y.; writing-original draft preparation, S.S.D.; writing—review and editing, A.Y.; supervision, A.Y.; project administration, A.Y. All authors have read and agreed to the published version of the manuscript.

Funding: This research received no external funding.

Institutional Review Board Statement: Not applicable.

Informed Consent Statement: Not applicable.

Data Availability Statement: The authors confirm that the data supporting the findings of this study are available within the article.

Acknowledgments: The CSIR-CSMCRI PRIS number for this manuscript is 029/2022. The authors thank B. Ganguly, CSIR-CSMCRI, for his help in theoretical calculations.

Conflicts of Interest: The authors declare no conflict of interest.

\section{References}

1. Satpute, S.D.; Jagtap, J.S.; Bhujbal, P.K.; Sonar, S.M.; Baviskar, P.K.; Jadker, S.R.; Pathan, H.M. Mercurochrome Sensitized $\mathrm{ZnO} / \mathrm{In}_{2} \mathrm{O}_{3}$ Photoanode for Dye-Sensitized Solar Cell. ES Energy Environ. 2020, 9, 89-94. [CrossRef]

2. Patel, R.V.; Yadav, A.; Winczek, J. Experimental Investigation and Mathematical Modelling of Heat Transfer Coefficient in Double Slope Solar Still. Strojniski Vestnik/J. Mech. Eng. 2021, 67, 369-379. [CrossRef]

3. Ejaz, A.; Jamil, F.; Ali, H.M. A novel thermal regulation of photovoltaic panels through phase change materials with metallic foam-based system and a concise comparison: An experimental study. Sustain. Energy Technol. Assess. 2021, 49, 101726. [CrossRef]

4. Iqbal, M.Z.; Ali, S.R.; Khan, S. Progress in dye sensitized solar cell by incorporating natural photosensitizers. Sol. Energy 2019, 181, 490-509. [CrossRef] 
5. Said, Z.; Ghodbane, M.; Tiwari, A.K.; Ali, H.M.; Boumeddane, B.; Ali, Z.M. 4E (Energy, Exergy, Economic, and Environment) examination of a small LFR solar water heater: An experimental and numerical study. Case Stud. Therm. Eng. 2021, $27,101277$. [CrossRef]

6. Hassan, F.; Jamil, F.; Hussain, A.; Ali, H.M.; Janjua, M.M.; Khushnood, S.; Farhan, M.; Altaf, K.; Said, Z.; Li, C. Recent advancements in latent heat phase change materials and their applications for thermal energy storage and buildings: A state of the art review. Sustain. Energy Technol. Assess. 2021, 49, 101646. [CrossRef]

7. Zhang, W.; Eperon, G.E.; Snaith, H.J. Metal halide perovskites for energy applications. Nat. Energy 2016, 1, 16048. [CrossRef]

8. Liu, M.; Johnston, M.; Snaith, H. Efficient planar heterojunction perovskite solar cells by vapour deposition. Nature 2013, 501, 395-398. [CrossRef]

9. Miles, R.W.; Zoppi, G.; Forbes, I. Inorganic photovoltaic cells. Mater. Today 2007, 10, 20-27. [CrossRef]

10. McCandless, B.E.; Sites, J.R. Cadmium Telluride Solar Cells. In Handbook of Photovoltaic Science and Engineering; Wiley: Chichester, UK, 2010; pp. 600-641.

11. Ameri, T.; Li, N.; Brabec, C.J. Highly efficient organic tandem solar cells: A follow up review. Energy Environ. Sci. 2013, 6, 2390-2413. [CrossRef]

12. Riede, M.; Uhrich, C.; Widmer, J.; Timmreck, R.; Wynands, D.; Schwartz, G.; Gnehr, W.-M.; Hildebrandt, D.; Weiss, A.; Hwang, J.; et al. Efficient Organic Tandem Solar Cells based on Small Molecules. Adv. Funct. Mater. 2011, 21, 3019-3028. [CrossRef]

13. Meng, L.; Zhang, Y.; Wan, X.; Li, C.; Zhang, X.; Wang, Y.; Ke, X.; Xiao, Z.; Ding, L.; Xia, R.; et al. Organic and solution-processed tandem solar cells with 17.3\% efficiency. Science 2018, 361, 1094-1098. [CrossRef] [PubMed]

14. Tvrdy, K.; Kamat, P. Quantum Dot Solar Cells. In Comprehensive Nanoscience and Technology; Elsevier BV: Amsterdam, The Netherlands, 2011; pp. 257-275.

15. Ning, Z.; Gong, X.; Comin, R.; Walters, G.; Fan, F.; Voznyy, O.; Yassitepe, E.; Buin, A.K.; Hoogland, S.; Sargent, E.H. Quantum-dotin-perovskite solids. Nature 2015, 523, 324-328. [CrossRef] [PubMed]

16. Pan, Z.; Rao, H.; Mora-Seró, I.; Bisquert, J.; Zhong, X. Quantum dot-sensitized solar cells. Chem. Soc. Rev. 2018, 47, 7659-7702. [CrossRef]

17. Dette, C.; Osorio, M.A.P.; Kley, C.S.; Punke, P.; Patrick, C.; Jacobson, P.; Giustino, F.; Jung, S.J.; Kern, K. TiO 2 Anatase with a Bandgap in the Visible Region. Nano Lett. 2014, 14, 6533-6538. [CrossRef]

18. Feldt, S.M.; Gibson, E.A.; Gabrielsson, E.; Sun, L.; Boschloo, G.; Hagfeldt, A. Design of Organic Dyes and Cobalt Polypyridine Redox Mediators for High-Efficiency Dye-Sensitized Solar Cells. J. Am. Chem. Soc. 2010, 132, 16714-16724. [CrossRef]

19. Kavan, L. Electrochemistry and dye-sensitized solar cells. Curr. Opin. Electrochem. 2017, 2, 88-96. [CrossRef]

20. Sugathan, V.; John, E.; Sudhakar, K. Recent improvements in dye sensitized solar cells: A review. Renew. Sustain. Energy Rev. 2015, 52, 54-64. [CrossRef]

21. Ruhane, T.; Islam, M.T.; Rahaman, S.; Bhuiyan, M.; Islam, J.M.; Newaz, M.; Khan, K.; Khan, M.A. Photo current enhancement of natural dye sensitized solar cell by optimizing dye extraction and its loading period. Optik 2017, 149, 174-183. [CrossRef]

22. Mao, X.; Zhou, R.; Zhang, S.; Ding, L.; Wan, L.; Qin, S.; Chen, Z.; Xu, J.; Miao, S. High Efficiency Dye-sensitized Solar Cells

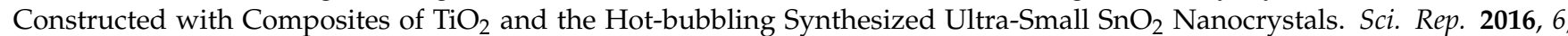
srep19390. [CrossRef]

23. Yi, Z.; Zeng, Y.; Wu, H.; Chen, X.; Fan, Y.; Yang, H.; Tang, Y.; Yi, Y.; Wang, J.; Wu, P. Synthesis, surface properties, crystal structure and dye-sensitized solar cell performance of $\mathrm{TiO}_{2}$ nanotube arrays anodized under different parameters. Results Phys. 2019, 15, 102609. [CrossRef]

24. Anouar, H.; Elhassan, A.; Hourch AEl Kacemi, K.E. Electronic and Optical Properties of Reactive Orange 16 azo dye. Int. J. Innov. Appl. Stud. 2014, 8, 1447-1454.

25. Yadav, V.; Chaudhary, S.; Negi, C.M.S.; Gupta, S.K. Textile dyes as photo-sensitizer in the dye sensitized solar cells. Opt. Mater. 2020, 109, 110306. [CrossRef]

26. Louis, H.; Onyebuenyi, I.B.; Odey, J.O.; Igbalagh, A.T.; Mbonu, M.T.; Eno, E.A.; Pembere, A.M.S.; Offiong, O.E. Synthesis, characterization, and theoretical studies of the photovoltaic properties of novel reactive azonitrobenzaldehyde derivatives. RSC Adv. 2021, 11, 28433-28446. [CrossRef]

27. Inamdar, Y.; Beedri, N.; Kodam, K.; Shaikh, A.; Pathan, H. Aggregation of ZnO Nanocrystallites Using Polyol Process for Dye (Reactive Red) Sensitized Solar Cell. Macromol. Symp. 2015, 347, 52-57. [CrossRef]

28. Sharma, K.; Sharma, V.; Sharma, S.S. Dye-Sensitized Solar Cells: Fundamentals and Current Status. Nanoscale Res. Lett. 2018, 13, 381. [CrossRef]

29. Janjua, M.R.S.A.; Khan, M.U.; Khalid, M.; Ullah, N.; Kalgaonkar, R.; Alnoaimi, K.; Baqader, N.; Jamil, S. Theoretical and Conceptual Framework to Design Efficient Dye-Sensitized Solar Cells (DSSCs): Molecular Engineering by DFT Method. J. Clust. Sci. 2021, 32, 243-253. [CrossRef]

30. Tian, H.; Yang, X.; Chen, R.; Zhang, R.; Hagfeldt, A.; Sun, L. Effect of Different Dye Baths and Dye-Structures on the Performance of Dye-Sensitized Solar Cells Based on Triphenylamine Dyes. J. Phys. Chem. C 2008, 112, 11023-11033. [CrossRef]

31. Xie, X.; Liu, Z.; Li, W.; Bai, F.-Q.; Lee, E.-C.; Zhang, H.-X. Theoretical study on organic dyes with tunable $\pi$-spacers for dye-sensitized solar cells: Inspired by the organic polymer photovoltaics. Chem. Phys. Lett. 2019, 719, 39-44. [CrossRef]

32. Xie, M.; Hao, L.; Jia, R.; Wang, J.; Bai, F.-Q. Theoretical study on the influence of electric field direction on the photovoltaic performance of aryl amine organic dyes for dye-sensitized solar cells. New J. Chem. 2019, 43, 651-661. [CrossRef] 
33. Delgado-Montiel, T.; Soto-Rojo, R.; Baldenebro-López, J.; Glossman-Mitnik, D. Theoretical Study of the Effect of Different $\pi$ Bridges Including an Azomethine Group in Triphenylamine-Based Dye for Dye-Sensitized Solar Cells. Molecules 2019, $24,3897$. [CrossRef] [PubMed]

34. Maurya, I.C.; Singh, S.; Srivastava, P.; Maiti, B.; Bahadur, L. Natural dye extract from Cassia fistula and its application in dye-sensitized solar cell: Experimental and density functional theory studies. Opt. Mater. 2019, 90, 273-280. [CrossRef]

35. Gao, F.; Yang, C.-L.; Jiang, G. Effects of the coupling between electrode and GQD-anthoxanthin nanocomposites for dye-sensitized solar cell: DFT and TD-DFT investigations. J. Photochem. Photobiol. A Chem. 2021, 407, 113080. [CrossRef]

36. Al-Temimei, F.A.; Alkhayatt, A.H.O. A DFT/TD-DFT investigation on the efficiency of new dyes based on ethyl red dye as a dye-sensitized solar cell light-absorbing material. Optik 2020, 208, 163920. [CrossRef]

37. Prajongtat, P.; Suramitr, S.; Nokbin, S.; Nakajima, K.; Mitsuke, K.; Hannongbua, S. Density functional theory study of adsorption geometries and electronic structures of azo-dye-based molecules on anatase $\mathrm{TiO}_{2}$ surface for dye-sensitized solar cell applications J. Mol. Graph. Model. 2017, 76, 551-561. [CrossRef]

38. Pounraj, P.; Mohankumar, V.; Pandian, M.S.; Ramasamy, P. The effect of different $\pi$-bridge configuration on bi-anchored triphenylamine and phenyl modified triphenylamine based dyes for dye sensitized solar cell (DSSC) application: A theoretical approach. J. Mol. Graph. Model. 2018, 79, 235-253. [CrossRef] [PubMed]

39. Qian, X.; Shao, L.; Li, H.; Yan, R.; Wang, X.; Hou, L. Indolo[3,2-b]carbazole-based multi-donor- $\pi$-acceptor type organic dyes for highly efficient dye-sensitized solar cells. J. Power Source 2016, 319, 39-47. [CrossRef]

40. Qian, X.; Yan, R.; Xu, C.; Shao, L.; Li, H.; Hou, L. New efficient organic dyes employing indeno[1,2-b]indole as the donor moiety for dye-sensitized solar cells. J. Power Source 2016, 332, 103-110. [CrossRef]

41. Guo, K.; Yan, K.; Lu, X.; Qiu, Y.; Liu, Z.; Sun, J.; Yan, F.; Guo, W.; Yang, S. Dithiafulvenyl Unit as a New Donor for High-Efficiency Dye-Sensitized Solar Cells: Synthesis and Demonstration of a Family of Metal-Free Organic Sensitizers. Org. Lett. 2012, 14, 2214-2217. [CrossRef]

42. Xia, H.-Q.; Kong, C.-P.; Wang, J.; Bai, F.-Q.; Zhang, H.-X. Design of D-A- $\pi-A$ organic dyes with different acceptor and auxiliary acceptor for highly efficient dye-sensitized solar cells: A computational study. RSC Adv. 2014, 4, 50338-50350. [CrossRef]

43. Ni, J.-S.; Yen, Y.-C.; Lin, J.T. Organic sensitizers with a rigid dithienobenzotriazole-based spacer for high-performance dyesensitized solar cells. J. Mater. Chem. A 2016, 4, 6553-6560. [CrossRef]

44. Irfan, A.; Aftab, H.; Al-Sehemi, A.G. Push-pull effect on the geometries, electronic and optical properties of thiophene based dye-sensitized solar cell materials. J. Saudi Chem. Soc. 2014, 18, 914-919. [CrossRef]

45. Kakiage, K.; Aoyama, Y.; Yano, T.; Oya, K.; Kyomen, T.; Hanaya, M. Fabrication of a high-performance dye-sensitized solar cell with $12.8 \%$ conversion efficiency using organic silyl-anchor dyes. Chem. Commun. 2015, 51, 6315-6317. [CrossRef]

46. Ganesan, P.; Yella, A.; Holcombe, T.W.; Gao, P.; Rajalingam, R.; Al-Muhtaseb, S.A.; Graetzel, M.; Nazeeruddin, M.K. Unravel the Impact of Anchoring Groups on the Photovoltaic Performances of Diketopyrrolopyrrole Sensitizers for Dye-Sensitized Solar Cells. ACS Sustain. Chem. Eng. 2015, 3, 2389-2396. [CrossRef]

47. Matta, S.K.; Kakiage, K.; Makuta, S.; Veamatahau, A.; Aoyama, Y.; Yano, T.; Hanaya, M.; Tachibana, Y. Dye-Anchoring Functional Groups on the Performance of Dye-Sensitized Solar Cells: Comparison between Alkoxysilyl and Carboxyl Groups. J. Phys. Chem. C 2014, 118, 28425-28434. [CrossRef]

48. Victor, A.; Pulidindi, I.N.; Kim, T.H.; Gedanken, A. Design of a selective solid acid catalyst for the optimization of glucose production from Oryza sativa straw. RSC Adv. 2016, 6, 31-38. [CrossRef]

49. Ikpesu, J.E.; Iyuke, S.E.; Daramola, M.; Okewale, A.O. Synthesis of improved dye-sensitized solar cell for renewable energy power generation. Sol. Energy 2020, 206, 918-934. [CrossRef]

50. Linares-Flores, C.; Schott, E.; Claveria-Cadiz, F.; Zarate, X. Energy conversion process of substituted phthalocyanines with potential application to DSSC: A theoretical study. Theor. Chim. Acta 2018, 137, 52. [CrossRef]

51. Zarate, X.; Schott, E.; Gomez, T.; Arratia-Pérez, R. Theoretical Study of Sensitizer Candidates for Dye-Sensitized Solar Cells: Peripheral Substituted Dizinc Pyrazinoporphyrazine-Phthalocyanine Complexes. J. Phys. Chem. A 2013, 117, 430-438. [CrossRef]

52. Frisch, M.J.; Trucks, G.W.; Schlegel, H.B.; Scuseria, G.E.; Robb, M.A.; Cheeseman, J.R.; Scalmani, G.; Barone, V.; Mennucci, B.; Petersson, G.A.; et al. Gaussian 09; Gaussian, Inc.: Wallingford, CT, USA, 2009.

53. Unny, D.; Sivanadanam, J.; Mandal, S.; Aidhen, I.S.; Ramanujam, K. Effect of Flexible, Rigid Planar and Non-Planar Donors on the Performance of Dye-Sensitized Solar Cells. J. Electrochem. Soc. 2018, 165, H845-H860. [CrossRef]

54. Becke, A.D. A new mixing of Hartree-Fock and local density-functional theories. J. Chem. Phys. 1993, 98, 1372-1377. [CrossRef]

55. Chen, X.-K.; Coropceanu, V.; Brédas, J.-L. Assessing the nature of the charge-transfer electronic states in organic solar cells. Nat. Commun. 2018, 9, 5295. [CrossRef]

56. Hanwell, M.D.; Curtis, D.E.; Lonie, D.C.; Vandermeersch, T.; Zurek, E.; Hutchison, G.R. Avogadro: An advanced semantic chemical editor, visualization, and analysis platform. J. Cheminform. 2012, 4, 17. [CrossRef] [PubMed]

57. Divya, V.V.; Suresh, C.H. Density functional theory study on the donating strength of donor systems in dye-sensitized solar cells. New J. Chem. 2020, 44, 7200-7209. [CrossRef]

58. Lu, T.; Chen, F. Multiwfn: A multifunctional wavefunction analyzer. J. Comput. Chem. 2012, 33, 580-592. [CrossRef]

59. O'Boyle, N.M.; Tenderholt, A.L.; Langner, K.M. cclib: A library for package-independent computational chemistry algorithms. J. Comput. Chem. 2008, 29, 839-845. [CrossRef] 
60. Sobhy, M.; Sofo, J.; Castleman, A. A density-functional study of the structural, electronic, and vibrational properties of $\mathrm{Ti}_{8} \mathrm{C}_{12}$ metallocarbohedrynes with relevance to ultrafast time-resolved spectroscopy. Femtochem. VII 2006, VII, 80-84. [CrossRef]

61. Fu, G.C. Transition-Metal Catalysis of Nucleophilic Substitution Reactions: A Radical Alternative to SN1 and SN2 Processes. ACS Central Sci. 2017, 3, 692-700. [CrossRef]

62. Balis, N.; Verykios, A.; Soultati, A.; Constantoudis, V.; Papadakis, M.; Kournoutas, F.; Drivas, C.; Skoulikidou, M.-C.; Gardelis, S.; Fakis, M.; et al. Triazine-Substituted Zinc Porphyrin as an Electron Transport Interfacial Material for Efficiency Enhancement and Degradation Retardation in Planar Perovskite Solar Cells. ACS Appl. Energy Mater. 2018, 1, 3216-3229. [CrossRef]

63. Bisht, R.; Fairoos, M.K.M.; Singh, A.K.; Nithyanandhan, J. Panchromatic Sensitizer for Dye-Sensitized Solar Cells: Unsymmetrical Squaraine Dyes Incorporating Benzodithiophene $\pi$-Spacer with Alkyl Chains to Extend Conjugation, Control the Dye Assembly on $\mathrm{TiO}_{2}$, and Retard Charge Recombination. J. Org. Chem. 2017, 82, 1920-1930. [CrossRef]

64. Pophristic, V.; Goodman, L. Hyperconjugation not steric repulsion leads to the staggered structure of ethane. Nature 2001, 411, 565-568. [CrossRef] [PubMed]

65. Ahmed, S.; Mushahary, B.C.; Kalita, D.J. Rational Design of Bay-Annulated Indigo (BAI)-Based Oligomers for Bulk Heterojunction Organic Solar Cells: A Density Functional Theory (DFT) Study. ACS Omega 2020, 5, 8321-8333. [CrossRef] [PubMed]

66. Seo, K.D.; Song, H.M.; Lee, M.J.; Pastore, M.; Anselmi, C.; De Angelis, F.; Nazeeruddin, M.K.; Gräetzel, M.; Kim, H.K. Coumarin dyes containing low-band-gap chromophores for Dye-sensitised solar cells. Dye. Pigment. 2011, 90, 304-310. [CrossRef]

67. Chitumalla, R.K.; Jang, J. Density functional theory study on ruthenium dyes and dye@ $\mathrm{TiO}_{2}$ assemblies for dye sensitized solar cell applications. Sol. Energy 2018, 159, 283-290. [CrossRef] 